\title{
TRENDS IN THE PREVALENCE OF PSYCHOACTIVE SUBSTANCE USE AMONG IŁAWA'S JUNIOR HIGH SCHOOL STUDENTS IN 2001-2014 ON THE BACKGROUND OF OTHER SURVEYS RESULTS
}

\author{
TRENDY W ROZPOWSZECHNIANIU UŻYWANIA \\ SUBSTANCJI PSYCHOAKTYWNYCH WŚRÓD IŁAWSKICH \\ GIMNAZJALISTÓW W LATACH 2001-2014 \\ NA TLE WYNIKÓW INNYCH BADAŃ
}

\author{
Krzysztof Bobrowski \\ Institute of Psychiatry and Neurology, Department of Public Health, Youth Prevention Unit Pro-M', Warsaw, Poland \\ Instytut Psychiatrii i Neurologii, Zakład Zdrowia Publicznego, Pracownia Profilaktyki Młodzieżowej „Pro-M”, Warszawa, Polska \\ Alcohol Drug Addict 2017; 30 (4): 223-248 \\ DOI: https://doi.org/10.5114/ain.2017.73875
}

\begin{abstract}
Introduction: The main aim of this paper is to present trends in the prevalence of psychoactive substance use among students from Iława, in comparison with trends observed in the ESPAD and the Warsaw/Mokotów studies.

Material and methods: The Iława study has been conducted since December 2001, repeated in years 2005, 2010, 2012 and 2014, in the whole local population of 15 -year old students (300 to 500 participants in each edition) applying always the same procedure. Trends in the prevalence of smoking, drinking alcohol and other psychoactive substance use were analysed.

Results: The last edition of the Iława study from 2014 revealed declines in the majority of substance use prevalence indicators over the last
\end{abstract}

Streszczenie

Wprowadzenie: Głównym celem pracy była prezentacja trendów $\mathrm{w}$ rozpowszechnieniu używania substancji psychoaktywnych wśród gimnazjalistów iławskich, na tle trendów w badaniach ESPAD oraz mokotowskich.

Materiał i metody: Badania iławskie prowadzono w 2001 r. i były powtarzane w 2005, 2010, 2012 i 2014 r., w całej lokalnej populacji 15-letnich uczniów (około 300 do 500 osób w każdej edycji badań), zawsze według tej samej procedury. Analizowano trendy $\mathrm{w}$ rozpowszechnieniu palenia papierosów, picia alkoholu oraz używania innych substancji psychoaktywnych.

Wyniki: Ostatnia edycja badań iławskich z 2014 r. przyniosła wyniki pokazujące spadki $\mathrm{w}$ okresie dwóch lat większości wskaźników używania substan-

Correspondence to/Adres do korespondencji: Krzysztof Bobrowski, Instytut Psychiatrii i Neurologii, Zakład Zdrowia Publicznego, Pracownia Profilaktyki Młodzieżowej „Pro-M”, ul. Sobieskiego 9, 02-957 Warszawa, phone: +48 224582 216, e-mail: kbob@ipin.edu.pl

Authors' contribution/Wkład pracy autorów: No ghostwriting declared./Nie występuje zjawisko ghostwriting.

Submitted/Otrzymano: 02.11.2017 • Accepted/Przyjęto do druku: 15.01.2018 
two years. In the same period, the consumption of designer drugs increased slightly (from 2.4 to $5.2 \%$ ) and the drug use rate remaining quite high (21\%).

Discussion: Long-term trends in the prevalence of cigarette, alcohol and drug use (including alcohol abstinence rates) in Iława study are clearly reflected the trends identified in nationwide survey ESPAD. Compared to the general population, prevalence of frequent drinking (the last 30 days) and binge drinking was lower among Iława's students and long-term trends were closer to the trends of the Warsaw students' subpopulation (Mokotów district).

Conclusions: The rather high percentage of drugs consumers suggests the need for greater control of supply on the illegal market. It is advisable to include universal prevention programmes among young people and prepare educators to conduct an intervention. These analyses have highlighted the need for more frequent monitoring of the epidemiological situation and the need for the development of binge drinking measurement standards.

Keywords: Alcohol, Binge drinking, Illegal and designer drugs, Epidemiology, Adolescents cji psychoaktywnych. W tym samym okresie wzrosła nieznacznie konsumpcja dopalaczy (z 2,4\% do 5,2\%), a wskaźnik używania narkotyków, po dużym wzroście w 2010 r., pozostał na dość wysokim poziomie, około $21 \%$.

Omówienie: Długoterminowe trendy w zakresie rozpowszechnienia palenia papierosów, picia alkoholu (odsetek abstynentów) oraz używania innych substancji psychoaktywnych w badaniach iławskich stanowią dość wierne odzwierciedlenie trendów identyfikowanych w badaniach ogólnopolskich ESPAD. W porównaniu z populacją ogólną rozpowszechnienie częstego picia alkoholu (ostatnie $30 \mathrm{dni}$ ) i upijania się (binge drinking) w populacji młodzieży iławskiej było mniejsze, a długoterminowe trendy bliższe były trendom w mokotowskiej subpopulacji młodzieży warszawskiej.

Wnioski: Dość duże odsetki konsumentów narkotyków sugerują konieczność większej kontroli ich podaży na nielegalnym rynku. Wskazane jest objęcie młodzieży programami profilaktyki uniwersalnej oraz przygotowanie wychowawców do podejmowania działań interwencyjnych. Przeprowadzone analizy uwidoczniły potrzebę częstszego monitorowania sytuacji epidemiologicznej oraz wypracowania właściwych standardów pomiaru upijania się.

Słowa kluczowe: alkohol, upijanie się, narkotyki, dopalacze, epidemiologia, młodzież

\section{- INTRODUCTION}

In presenting the Iława study, we ought to devote a few words to the characteristics of the town itself. Iława's history stretches back over 700 years to when it was founded by the Order of Teutonic Knights. Afterwards it became part of Prussia for a number of centuries, then Germany, before becoming a Polish town in 1945. Its picturesque location on Jeziorak, the longest lake in Poland, together with the Elbląg canal, forms a watercourse leading all the way to the Baltic. Surrounded by numerous nature reserves, it boasts many recreational and touristic attractions. The last 25 years have been characterised by dynamic investment-led development and a very low level of unemployment (around 6\%) considered in terms of the Warmia and Mazury region.

Iława is a district administrative centre with around 33,000 residents. Cities of this size (up

\section{W Wrowadzenie}

Prezentując badania iławskie, kilka słów trzeba poświęcić charakterystyce samego miasta. Iława ma ponad 700-letnią historię. Założona została jako miasto krzyżackie, następnie przez kilka wieków była w granicach Prus, potem Niemiec i dopiero w 1945 r. stała się miastem polskim. Jest malowniczo położona nad najdłuższym jeziorem w Polsce - Jeziorakiem, które wraz z kanałem elbląskim tworzy szlak wodny prowadzący aż do Bałtyku. Otoczona licznymi rezerwatami przyrody, posiada duże walory rekreacyjne i turystyczne. W ostatnim 25-leciu cechował miasto dynamiczny rozwój inwestycyjny oraz bardzo niski w skali województwa warmińsko-mazurskiego poziom bezrobocia (około 6\%).

Iława jest miastem powiatowym, liczącym około 33 tys. mieszkańców. Miasta tej wielkości (do 
to 50,000 residents) are characterised by a higher-than-national-average prevalence of alcohol problems (especially among males) and on the other hand a lower prevalence of drug-use related problems. Residents of small towns enjoy relatively good mental health as demonstrated by at least the rather low suicide rate compared to larger urban centres [1].

The recreational nature of the surroundings may have significance for young persons' lifestyle and favour tendencies to drink alcohol and the use of other psychoactive substances. On the other hand, the large number of local sport clubs with considerable achievements and a developed cultural scene in the city may favour the development of young people's interests and passions protecting them from involvement in problem behaviour.

The results of the Iława studies have for many years formed the important empirical base for the local prevention programme construction [2]. Successive study reports and results, articles are published and presented to representatives of the most important local institutions [3]. Information on the studies also reaches a significant part of Iława's residents [4].

Various types of preventative activity has been developed based on the conclusions drawn from studies including the systematic realisation of evidence-based universal prevention programmes on a wider scale addressed to 10-to-13-year-old school students.

This work presents the long-term trends in the prevalence of psychoactive substance use among 13-to-15-year-old school students in Iława observed between 2001 and 2014 [5-8]. We have compared these with trends identified in Polish nationwide studies carried out within the European School Survey Project on Alcohol and Drugs (ESPAD) [9-11] as well as studies conducted over 30 years in the Warsaw district of Mokotów by the Institute of Psychiatry and Neurology Youth Prevention Unit 'Pro-M' [12-16].

One can mention a number of advantages of relating the results of local population studies to that of other studies. Generally, this greatly broadens the possibility of assessing the results of local studies. Comparison of long-term trends allows us to conclude whether the course of change in the prevalence of alcohol or drugs use is similar
50 tys. mieszkańców) charakteryzują się wyższym od przeciętnego w Polsce rozpowszechnieniem problemów alkoholowych (szczególnie wśród mężczyzn), a $\mathrm{z}$ drugiej strony - niższym rozpowszechnieniem problemów związanych z używaniem narkotyków. Mieszkańcy niewielkich miast cieszą się względnie dobrą kondycją psychiczną, o czym świadczy chociażby dość niski wskaźnik samobójstw w porównaniu $\mathrm{z}$ większymi miejscowościami [1].

Rekreacyjny charakter otoczenia może mieć znaczenie dla stylu życia młodzieży i sprzyjać tendencjom do picia alkoholu i używania innych substancji psychoaktywnych. Z drugiej strony, mnogość iławskich klubów sportowych o znaczących osiągnięciach i rozwinięta działalność kulturalna na terenie miasta mogą sprzyjać rozwojowi zainteresowań i życiowych pasji młodzieży, a tym samym chronić ją przed angażowaniem się w zachowania problemowe.

Wyniki badań iławskich od wielu lat stanowią ważną, merytoryczną podstawę konstrukcji miejskiego programu profilaktyki [2]. Publikowane kolejne raporty i wyniki badań oraz artykuły prezentowane są przedstawicielom najważniejszych instytucji lokalnych [3]. Informacja o badaniach dociera także do znacznej części mieszkańców Iławy [4].

W związku z wnioskami płynącymi z badań rozwijano różnego typu działania profilaktyczne, m.in. na szerszą skalę zaczęto systematycznie realizować sprawdzone, skuteczne programy profilaktyki uniwersalnej adresowane do uczniów klas IV-VI szkół podstawowych.

W pracy prezentowane są długoterminowe trendy $\mathrm{w}$ rozpowszechnieniu używania substancji psychoaktywnych wśród gimnazjalistów w Iławie, obserwowane $w$ latach 2001-2014 [5-8]. Porównujemy je $\mathrm{z}$ trendami wynikającymi z badań ogólnopolskich, prowadzonych $\mathrm{w}$ ramach Europejskiego Programu Badań Ankietowych ESPAD (European School Survey Project on Alcohol and Drugs) [9-11] oraz z badań realizowanych od ponad 30 lat na warszawskim Mokotowie przez Pracownię Profilaktyki Młodzieżowej „Pro-M” Instytutu Psychiatrii i Neurologii [12-16].

Można wymienić kilka korzyści, jakie daje odniesienie wyników lokalnych badań populacyjnych do wyników innych badań. Mówiąc ogólnie, poszerza to znacznie możliwości oceny wyników lokalnych badań. Porównanie długoterminowych trendów pozwala stwierdzić, czy przebieg zmian $\mathrm{w}$ rozpowszechnieniu używania alkoholu czy narkotyków 
for local and national studies or different. It is therefore possible to assess whether and in what period of time the observed changes are in accordance with national (or Warsaw) trends and are likely to be derivative of general trends or whether they reflect local specifics. And finally, data from other studies may provide a point of reference for the assessment of the current scale of the prevalence of psychoactive substance use in a given population.

Both the Iława study and the two remaining research projects were conducted among 15-year-old school students, which gives us the basis for comparison of results. However the studies differ in terms of the times of their realisation. In the case of the Mokotów study, we have a two years difference in relation to the Iława study edition in 2014. The Iława study and ESPAD were last conducted in the same school year, though with a half-year time difference. The above circumstances show that the ESPAD study results are a more current point of reference for the assessment of the epidemiological situation in the population of Iława students than the Mokotów study.

In attempting to compare the results of various population studies, we encounter further problems and limitations. Above all, there are different scopes of study so we only have the possibility of comparison in a narrow range of variables. Furthermore, in relation to the same analysed variables, different indicators were applied in different studies. And even if they are analogical, they are often measured on the basis of respondents' answers to survey questions formulated in a different way [17].

The above problems do not concern comparisons of the Iława and Mokotów studies because the range of survey questions in both studies is nearly identical. And even if sometimes different indicators or a different method of their calculation were applied, access to databases gave the opportunity to standardise and convert the results. Many more problems appear in the comparison of Iława or Mokotów studies with ESPAD due to differences in survey questions. There is however a number of analogical indicators that create the possibility of comparing the study results.

It is also worth mentioning the important events on the national drugs scene in 2007-2016, jest podobny w badaniach lokalnych i ogólnopolskich, czy też różny. Można zatem próbować ocenić, czy i w jakim okresie obserwowane zmiany są zgodne $\mathrm{z}$ trendami ogólnopolskimi (lub warszawskimi) i prawdopodobnie stanowią pochodną ogólnych trendów czy też odzwierciedlają, być może, lokalną specyfikę. I w końcu, dane z innych badań mogą stanowić punkt odniesienia dla oceny aktualnej skali rozpowszechnienia używania substancji psychoaktywnych w określonej populacji.

Zarówno badania iławskie, jak i dwa pozostałe projekty badawcze są prowadzone wśród uczniów klas III gimnazjum, co daje podstawę do porównania wyników. Badania różnią się natomiast terminami, w których je realizowano. W przypadku badań mokotowskich mamy dwuletnie przesunięcie w czasie pomiaru w stosunku do edycji badań iławskich z 2014 r. Badania iławskie i ESPAD prowadzono ostatnio w tym samym roku szkolnym, ale z półrocznym przesunięciem terminów. Powyższe okoliczności pokazują, że wyniki badania ESPAD są bardziej aktualnym punktem odniesienia dla oceny sytuacji epidemiologicznej w populacji iławskich gimnazjalistów niż badań mokotowskich.

Podejmując próbę porównywania wyników różnych badań populacyjnych, napotykamy jeszcze inne problemy i ograniczenia. Przede wszystkim bywają różne zakresy badań, mamy zatem możliwość dokonywania porównań tylko w obrębie wąskiej puli zmiennych. Z kolei w odniesieniu do tych samych analizowanych zmiennych, w różnych badaniach bywają stosowane inne wskaźniki. A jeśli nawet są one analogiczne, to często obliczane na podstawie odpowiedzi respondentów na różnie formułowane pytania ankietowe [17].

Powyższe problemy nie dotyczą porównywanych tu wyników badań iławskich i mokotowskich, ponieważ $\mathrm{w}$ obu badaniach pula pytań ankietowych jest niemal identyczna. I nawet jeśli stosowane były czasem inne wskaźniki czy inny sposób ich obliczania, dostęp do baz danych dawał możliwość ujednolicenia i przeliczenia wyników. Dużo więcej problemów pojawia się przy porównaniach badań iławskich czy mokotowskich z ESPAD ze względu na różnice w pytaniach ankietowych. Jest jednak kilka analogicznych wskaźników, które dają możliwość porównania wyników badań.

Warto jeszcze wspomnieć o istotnych wydarzeniach w latach 2007-2016 na krajowej scenie narkotykowej, które mogły mieć znaczenie dla obserwowanych trendów lokalnych czy ogólnopolskich. 
which could have had a bearing on the observed local or national trends. In this time we noted great changes in the supply and availability of so called new psychoactive substances, known popularly as designer drugs or legal highs. The Polish specialists in this area, P. Jabłoński and A. Malczewski [18: 3], defined them as 'different kinds of substances and products revealing supposed or actual psychoactive effects. These substances could be of natural or synthetic origin and their defining feature is the fact they are not on any list of controlled substances under international or national law'.

According to the Supreme Audit Office there were around 50 outlets with designer drugs functioning in the whole country in 2007, and then in 2008-2010, their number drastically increased to nearly 1400 [19]. In October 2010, the Chief Sanitary Inspectorate, due to the increasing number of cases of severe designer drug poisonings, took the decision to close all of this kind of shops. The distribution of designer drugs was drastically limited. From 2011, this started to gradually re-establish itself though on a more limited scale via the internet and the reopening of points of sale in cities, which in 2014 and 2015 amounted to over 200, and then halved in number in $2016[18,20]$.

The basic aims of the presented work were as follows:

1. Assessment of the current prevalence of psychoactive substances use in the population of 15 year-old students in Iława, mainly in relation to the data from the national ESPAD survey.

2. Analysis of long-term trends in the prevalence of alcohol drinking and use of other psychoactive substances by Iława school students against the background of trends observed in the national ESPAD studies and Mokotów study realised in Warsaw.

3. Analysis of changes in the availability of new psychoactive substances and an attempt to answer whether these were reflected in the results of population studies and observed trends.
W tym okresie mieliśmy do czynienia z gwałtownymi zmianami w podaży i dostępności tzw. nowych substancji psychoaktywnych, zwanych potocznie „dopalaczami”. Polscy specjaliści w tej dziedzinie, P. Jabłoński i A. Malczewski [18: 3], określają je jako: „różnego rodzaju substancje i produkty wykazujące rzekome lub faktyczne działanie psychoaktywne. Substancje te mogą być pochodzenia naturalnego lub syntetycznego, a ich cechą wyróżniającą jest fakt, że nie znajdują się w wykazach substancji kontrolowanych prawem międzynarodowym czy krajowym".

Według ustaleń Najwyższej Izby Kontroli, w 2007 r. na terenie całego kraju funkcjonowało około 50 sklepów z dopalaczami, a następnie w latach 2008-2010 ich liczba drastycznie wzrosła do blisko 1400 [19]. W październiku 2010 r. Główny Inspektorat Sanitarny (GIS), w związku z narastaniem liczby ciężkich zatruć dopalaczami, podjął decyzję o zamknięciu wszystkich tego typu sklepów. Dystrybucja dopalaczy została raptownie ograniczona. Od 2011 r. zaczęła się stopniowo odradzać, choć $\mathrm{w}$ ograniczonej skali, przez internet oraz ponownie uruchamiane $\mathrm{w}$ miastach punkty sprzedaży, których liczba w latach 2014 i 2015 przekroczyła 200, a następnie spadła o połowę w 2016 r. [18, 20].

Zasadnicze cele prezentowanej pracy były następujące:

1. Ocena aktualnego rozpowszechnienia substancji psychoaktywnych w populacji klas III iławskich gimnazjalistów, w odniesieniu głównie do danych z ogólnopolskich badań ESPAD.

2. Analiza długoterminowych trendów w rozpowszechnieniu picia alkoholu i używania innych substancji psychoaktywnych przez iławskich gimnazjalistów na tle trendów obserwowanych w ogólnopolskich badaniach ESPAD oraz w badaniach mokotowskich, realizowanych w Warszawie.

3. Analiza zmian w dostępności nowych substancji psychoaktywnych i próba odpowiedzi na pytanie, czy znalazły one odzwierciedlenie w wynikach badań populacyjnych i obserwowanych trendach. 


\section{- Material And methods}

\section{Research procedure}

The Iława survey study is realised according to the same procedure since 2001. These are carried out with the auditorium survey method during one 45-minute lesson, in a manner assuring the maintenance of individual students' class and school anonymity. The students are informed of the anonymity and of the voluntary basis of participation in the study. Written information is prepared specially for parents together with a request to report to the school any problems or questions relevant to the matter. Depending on the decision of the school director, information is sent to all parents or they may read it at the school, where it is also possible to see the content of the survey questionnaire.

The school study is organised by the Mayor of Iława’s representative for family, prevention and addiction problems as well as the Centre for Psychoeducation, Addiction Prevention and Family Assistance. The surveyors are persons from outside the school system, university students - volunteers cooperating with the Centre or its young employees. The surveyors are trained and receive written instructions according to which they inform the respondents about the studies and method of answering the survey questions.

The Mokotów studies and ESPAD, which present a reference point to the Iława research, are realised according to very similar standard procedures $[11,16]$. There were certain differences concerning organisation. In the ESPAD studies, contacts with the schools are part of the surveyors and local research coordinators scope of duties. In the Mokotów studies, the study team is responsible for organisation and coordination, and they employ the surveyors, who are usually university students. It has occurred that, due the lack of financial resources of study, research workers have done the surveying work.

\section{Research of groups}

The Iława studies were carried out between 2001 and 2014 in five editions. According to initial assumptions, they were supposed to be repeated systematically every four years. There were, however, exceptions. The period between two editions (2005-2010) was extended to 5 years at the main organising Representative's request. The time of study result announcement coincided awkwardly with

\section{- Materiat I metody}

\section{Procedura badań}

Iławskie badania ankietowe realizowane są według tej samej procedury od 2001 r. Prowadzone są metodą audytoryjną w czasie jednej 45-minutowej lekcji, w sposób zapewniający zachowanie anonimowości poszczególnym uczniom, klasom i szkołom. Uczniów informuje się o anonimowości oraz o zasadzie dobrowolności udziału w badaniach. Specjalnie dla rodziców przygotowana jest pisemna informacja o badaniach, wraz z prośbą o zgłaszanie do szkoły wszelkich problemów lub pytań związanych z tą sprawą. W zależności od decyzji dyrekcji, powieloną informację wysyła się wszystkim rodzicom lub mogą oni przeczytać ją w szkole, gdzie jest również możliwość zapoznania się z treścią ankiety.

Organizacją badań w szkołach zajmuje się Pełnomocnik Burmistrza Iławy ds. Rodziny, Profilaktyki i Rozwiązywania Problemów Uzależnień oraz Ośrodek Psychoedukacji, Profilaktyki Uzależnień i Pomocy Rodzinie. Funkcję ankieterów pełnią osoby spoza systemu oświaty, studenci - wolontariusze współpracujący z Ośrodkiem lub jego młodzi pracownicy. Ankieterzy są szkoleni i otrzymują pisemną instrukcję, według której informują uczniów o badaniach i sposobie odpowiadania na pytania ankietowe.

Badania mokotowskie i ESPAD, stanowiące odniesienie dla badań iławskich, realizowane są według bardzo podobnych standardowych procedur $[11,16]$. Pewne różnice dotyczą ich organizacji. W badaniach ESPAD kontakty ze szkołami należą do zadań ankieterów i lokalnych koordynatorów badań. W badaniach mokotowskich organizacją i koordynacją badań zajmuje się zespół badawczy, który zatrudnia ankieterów, najczęściej studentów. Zdarzało się, że z powodu niedostatku środków finansowych na naukę w rolę ankieterów wcielali się pracownicy naukowi.

\section{Badane grupy}

Badania iławskie prowadzone były w latach 2001-2014 w pięciu edycjach. Według wstępnych założeń miały być powtarzane systematycznie co cztery lata. Były jednak wyjątki. Okres między kolejnymi edycjami badań (2005-2010) wydłużono do 5 lat na prośbę Pełnomocnika, głównego organizatora badań. Czas ogłaszania wyników badań zbiegał się bowiem niefortunnie z okresem kampanii przed wyborami samorządowymi. Po- 
Trends in the prevalence of psychoactive substance use...

Trendy w rozpowszechnianiu używania substancji psychoaktywnych...

Table I. Characteristic of the sample and its size in subsequent studies

Tabela I. Charakterystyka próby oraz jej liczebność w kolejnych edycjach badań

\begin{tabular}{|c|c|c|c|c|c|c|c|c|}
\hline \multirow[b]{2}{*}{$\begin{array}{l}\text { Year }^{1} \\
\text { Rok }\end{array}$} & \multicolumn{2}{|c|}{$\begin{array}{l}\text { No of classes } \\
\text { Liczba klas }\end{array}$} & \multicolumn{3}{|c|}{$\begin{array}{l}\text { No of students } \\
\text { Liczba uczniów }\end{array}$} & \multicolumn{3}{|c|}{$\begin{array}{l}\text { Percent } \\
\text { Odsetki }\end{array}$} \\
\hline & $\begin{array}{l}\text { Population } \\
\text { Populacja }\end{array}$ & $\begin{array}{l}\text { Sample } \\
\text { Próba }\end{array}$ & $\begin{array}{l}\text { Population² } \\
\text { Populacja }\end{array}$ & $\begin{array}{l}\text { Sample } \\
\text { Próba }\end{array}$ & $\begin{array}{c}\text { Reliable } \\
\text { questionnaires } \\
\text { Wiarygodne } \\
\text { ankiety }\end{array}$ & $\begin{array}{l}\text { Percent } \\
\text { Odsetki }\end{array}$ & $\begin{array}{c}\text { Sex - girls } \\
\text { Płeć - } \\
\text { dziewczęta }\end{array}$ & $\begin{array}{l}\text { Delayed in } \\
\text { learning } \\
\text { Opóźnieni } \\
\text { w nauce }\end{array}$ \\
\hline 2001 & 23 & 21 & 585 & 510 & 503 & $86 \%$ & $47.8 \%$ & $2.8 \%$ \\
\hline 2005 & 18 & 18 & 481 & 428 & 426 & $89 \%$ & $57.6 \%$ & $6.3 \%$ \\
\hline 2010 & 15 & 15 & 376 & 323 & 322 & $86 \%$ & $50.6 \%$ & $3.7 \%$ \\
\hline 2012 & 12 & 12 & 319 & 300 & 294 & $92 \%$ & $49.8 \%$ & $4.1 \%$ \\
\hline 2014 & 15 & 15 & 361 & 313 & 307 & $85 \%$ & $54.8 \%$ & $6.9 \%$ \\
\hline
\end{tabular}

${ }^{1}$ Also studied were 13 year-old school students as were 17 year-olds in 2001, though this data was not included in the study./Badano jeszcze uczniów klas I gimnazum, a w 2001 r. także uczniów klas II szkót ponadgimnazjalnych starego typu; dane na ten temat pominięto.

${ }^{2}$ The data from the class diaries was collected by surveyors./Dane z dzienników lekcyjnych zebrane przez ankieterów.

local government election campaigning. Furthermore, in the face of the great dynamic of indicator change and the increase of the prevalence of substance use between 2005 and 2010, additional studies were carried out (2012) in order to more precisely monitor the epidemiological situation [8].

Due to the small size of the Iława population, no sample was taken and the study covered the entire population of 15 year-old school students. As table I shows, the size of the study group ranged from around 500 students in 2001 to around 300 in the last editions in 2012 and 2014. Depending on the edition, $85 \%$ to $92 \%$ of 15 year-old students in the Iława schools returned their surveys correctly filled in.

The proportion of girls in the studied groups varied in each edition between $47.8 \%$ and $54.8 \%$ and the older students repeating the year ranged from $2.8 \%$ to $6.9 \%$.

In the compared trends, we took into account five of the last Mokotów studies from 2000 to 2016 and ESPAD from 1999 to 2015. In the Mokotów studies, we usually selected at least a half of 15-year-old classes at random in the area of three Warsaw districts - Mokotów, Ursynów and Wilanów, and the samples numbered usually a thousand or more students (760 in the last edition). In the national ESPAD study, the random selection was two-stage. First the schools were drawn, followed by a selection of one class from each school. The samples in these studies included over 2200 15-year-old students (older students involved in the ESPAD studies were not taken into account in our research). nadto, wobec dużej dynamiki zmian wskaźników i wzrostu rozpowszechnienia używania substancji między 2005 i 2010 r., w 2012 r. przeprowadzono dodatkowe badania w celu bardziej dokładnego monitorowania sytuacji epidemiologicznej [8].

Ze względu na niewielką liczebność iławskiej populacji nie dobierano próby, a badania obejmowały całą populację uczniów z klas III miejskich gimnazjów. Jak pokazano $\mathrm{w}$ tabeli I, wielkość badanej grupy wahała się od około 500 uczniów w 2001 r. do około $300 \mathrm{w}$ ostatnich edycjach w latach 2012 i 2014 . W zależności od edycji, 85\% do 92\% uczniów klas III iławskich gimnazjów oddawało poprawnie wypełnione ankiety.

W kolejnych edycjach odsetek dziewcząt w badanych grupach był zmienny i wynosił od $47,8 \%$ do $54,8 \%$, a odsetek uczniów starszych rocznikiem, prawdopodobnie „drugorocznych”, wahał się od $2,8 \%$ do $6,9 \%$.

W porównaniach trendów uwzględniono pięć ostatnich edycji badań mokotowskich $\mathrm{z}$ lat 2000 2016 oraz ESPAD z okresu 1999-2015. W badaniach mokotowskich zwykle dobierano losowo co najmniej połowę wszystkich klas III z terytorium obejmującego trzy dzielnice Warszawy: Mokotów, Ursynów i Wilanów, a próby liczyły zwykle tysiąc i więcej uczniów (w ostatniej edycji - 760). W ogólnopolskich badaniach ESPAD dobór losowy był dwustopniowy. Najpierw losowano szkoły, a następnie jedną klasę z każdej szkoły. Próby w tych badaniach liczą ponad 2200 gimnazjalistów z III klas (pominięto tutaj uczniów II klas szkół ponadgimnazjalnych także badanych w ESPAD). 


\section{Tools and indicators}

As has already been mentioned, the majority of questions applied in the Iława studies, concerned drinking alcohol and the use of other psychoactive substances were sourced from the Mokotów studies [21]. As a result, the variable indicators for both studies were identical. In order to make long-term trend comparisons of the prevalence of psychoactive substance use, a number of indicators were selected that were most similar to those applied in ESPAD studies.

\section{Cigarette smoking}

In the Iława and Mokotów studies, students' answers to the question 'Do you smoke cigarettes?' were the basis for the creation of two indicators. The first defined the percentage of actual cigarette smokers and the second described the percentage of daily smokers. In the ESPAD study, current smoking was measured (from 2003) on the basis of the question 'How often have you smoked cigarettes in the last 30 days?' One of the answer categories described the daily cigarette smoking. On the basis of data from 2003 to 2015 revealed in the ESPAD research report [11], it was possible to calculate the values of similar indicators as in the Iława and Mokotów studies.

\section{Drug use}

There are no questions on the frequency of marijuana or other drug use in the Iława and Mokotów studies, only general question. Students were asked whether they had used any illicit drugs (including inhalants) in the last year, with the choice of any five answer categories: no, it has not happened, yes, one or two times, yes, a several times, yes, a dozen and so times or yes more than a dozen and so times. The main indicator was the percentage of young people who declared they had used any illicit drugs at least once in the last year.

In the ESPAD reports there is only data on the frequency of the use of particular psychoactive substances. In these circumstances, we attempted to estimate the indicator of any illicit drug use (including inhalants) on the basis of information available from ESPAD on the use of marijuana (or hashish) in the last 12 months.

\section{Narzędzia i wskaźniki}

Jak już wspomniano, większość pytań ankietowych stosowanych w badaniach iławskich, dotyczących picia alkoholu i używania innych substancji psychoaktywnych, zaczerpnięto z kwestionariusza używanego w badaniach mokotowskich [21]. W konsekwencji także wskaźniki zmiennych były w obu badaniach identyczne. Do porównań długoterminowych trendów w rozpowszechnieniu używania substancji psychoaktywnych wybrano kilka wskaźników, najbardziej podobnych do tych stosowanych w badaniach ESPAD.

\section{Palenie papierosów}

W badaniach iławskich i mokotowskich odpowiedzi uczniów na pytanie: „Czy palisz papierosy?”, były podstawą do skonstruowania dwóch wskaźników. Pierwszy określał odsetek aktualnych palaczy papierosów, a drugi opisywał odsetek palących papierosy codziennie. W badaniach ESPAD bieżące palenie mierzone było (od 2003 r.) na podstawie pytania: „Jak często paliłeś papierosy w ciągu ostatnich 30 dni?". Wśród kategorii odpowiedzi wyróżniano także codzienne palenie papierosów. Na podstawie danych $z$ lat 2003-2015, przytaczanych $\mathrm{w}$ raporcie $\mathrm{z}$ badań ESPAD [11], możliwe było obliczenie wartości podobnych wskaźników, jak w badaniach iławskich i mokotowskich.

\section{Używanie narkotyków}

W badaniach iławskich i mokotowskich nie ma pytań o częstość używania marihuany czy innych narkotyków, lecz jest pytanie ogólne. Uczniowie byli pytani o używanie w ostatnim roku „środków narkotyzujących", z wyborem jednej z pięciu kategorii odpowiedzi: nie zdarzyło sie, tak - jeden lub dwa razy, tak - kilka razy, tak - kilkanaście razy oraz tak - więcej niż kilkanaście razy. Głównym wskaźnikiem był odsetek młodzieży deklarującej używanie jakichkolwiek „środków narkotyzujących" przynajmniej raz w ciągu ostatniego roku.

W raportach ESPAD publikowane są tylko dane dotyczące częstości używania poszczególnych substancji psychoaktywnych. Wobec takich okoliczności, na użytek niniejszej pracy podjęto próbę oszacowania wskaźnika używania jakichkolwiek „środków narkotyzujących” na podstawie dostępnych informacji z ESPAD o używaniu w ostatnich 12 miesiącach marihuany (lub haszyszu). 
In annual reports from youth population surveys in the US Monitoring the Future (MTF) [22], the percentages of class 10 students who had used any illicit drugs (including inhalants) in the last year was published, together with the percentages using marijuana or hashish. On the basis of data from the last 20 years, it was calculated that the proportion between the abovementioned two indicators was on average 1.17. The estimated indicators for further ESPAD studies were calculated by multiplying by that figure (1.17) the percentage of students using marijuana at least once in the last year. It ought to be explained that American studies were used here due to the lack of Polish research that would allow the estimation of the proportion between the two indicators discussed here.

\section{Designer drugs use}

The inspiration to develop diagnostic questions on the prevalence of designer drugs was the Public Opinion Research Centre (CBOS) study on young people $[18,23,24]$. The surveys, both in for the Iława and ESPAD studies, designer drugs were defined in a very similar manner as 'substances acting on the psyche and sold in specialist shops or on the internet'. The use of designer drugs in the last 12 months was the only indicator applied for comparison of results of both studies. In the Iława study, students were asked 'Did you use designer drugs...' and in the ESPAD study 'How many times have you used designer drugs...?' The answer categories were analogical from 0/not once, 1-2 times to 10-19 times. In the Iława study, the last category was 20 times or more and in ESPAD there was an additional seventh category 40 times or more.

In the Mokotów studies, unlike the other research, students were not asked specifically about designer drugs, and no definition was provided either. There were however questions on the types of psychoactive substances used and respondents could select designer drugs from a list of different substances. Due to such a great difference in the content of questions, it was decided that in the scope of designer drug use it was possible to compare only the results of the Iława and ESPAD studies.

\section{Drinking alcohol}

In the Mokotów, like in Iława studies, respondents were asked about the last case of drinking
$\mathrm{W}$ raporcie $\mathrm{z}$ badań populacyjnych młodzieży w USA Monitoring the Future (MTF) [22], realizowanych corocznie, prezentowane są odsetki uczniów z klas 10, którzy w ostatnim roku używali jakichkolwiek nielegalnych substancji, w tym środków wziewnych, a także odsetki używających marihuany lub haszyszu. Na podstawie danych z ostatnich 20 lat obliczono, że proporcja między powyższymi dwoma wskaźnikami wynosiła średnio 1,17. Estymowane wskaźniki dla kolejnych edycji badań ESPAD obliczono, mnożąc przez tę liczbę odsetki uczniów używających marihuany przynajmniej raz w ostatnim roku. Należy wyjaśnić, że posłużono się amerykańskimi badaniami ze względu na brak polskich badań, które umożliwiałyby oszacowanie proporcji między omawianymi tu wskaźnikami.

\section{Używanie dopalaczy}

Inspirację do opracowania pytań diagnozujących rozpowszechnienie dopalaczy stanowily badania młodzieży CBOS $[18,23,24]$. W ankietach, zarówno badań iławskich, jak i ESPAD, dopalacze definiowano w bardzo podobny sposób: „«Dopalacze» lub «smarty» to substancje działające na psychikę, sprzedawane w specjalnych sklepach lub przez internet”. Do porównań wyników obu badań wykorzystano tylko jeden wskaźnik - używanie dopalaczy przynajmniej raz $\mathrm{w}$ ciągu ostatnich 12 miesięcy. W badaniach iławskich pytano uczniów: „Czy używałeś «dopalaczy»...?", a w ESPAD: „Ile razy używałeś «dopalaczy»...?”. Kategorie odpowiedzi były analogiczne: od 0/ani razu, 1-2 razy do 10-19 razy. W badaniach iławskich ostatnia kategoria to 20 lub więcej razy, a w ESPAD była dodatkowa, siódma: 40 lub więcej razy.

W badaniach mokotowskich, w odróżnieniu od pozostałych badań, nie zadawano uczniom osobnego pytania o używanie dopalaczy, nie podano również ich definicji. Pytano natomiast o rodzaje używanych substancji psychoaktywnych i w odpowiedzi badani mogli zaznaczyć dopalacze na kilkupunktowej liście substancji. W związku z tak dużymi różnicami w treści pytań ankietowych uznano, że w zakresie używania dopalaczy możemy porównać tylko wyniki badań iławskich i ESPAD.

\section{Picie alkoholu}

W badaniach mokotowskich, i w ślad za nimi w badaniach iławskich, pytano respondentów 
specific alcoholic beverages like beer, wine (including champagne and home-made wine) and vodka (and other strong liquor like whisky, gin or cognac), when this took place and how much they had drunk. Respondents could choose categories like I never drank. Other possible answers to the question 'when?' included 8 categories from over a year ago to 1 to 4 days ago. It was on this basis that the indicators analysed in this work were calculated; that is 'the percentage of alcohol abstainers' and 'the percentage of alcohol drinkers in the last 30 days'. The concept of abstinence was defined as, together with other Polish researchers, 'not drinking any alcoholic beverages in the last 12 months immediately prior to the moment of study' [25: 7].

In the ESPAD survey, another more general type of question was applied about the frequency of alcohol drinking in the last 12 months and last 30 days 'How many times (if at all) did you drink some alcohol beverage like beer, wine, vodka or other liquor?' Despite the differences in the question formulation, it was possible to count analogous indicators of alcohol drinking like in the Iława and Mokotów studies.

\section{Binge drinking}

All the three compared studies analysed the indicator concerning binge-drinking episodes. This is the main indicator of alcohol drinking levels recommended for use in population studies for institutions significant for federal health policy in the USA like the National Institute on Alcohol Abuse and Alcoholism (NIAAA) and Substance Abuse and Mental Health Services Administration (SAMHSA). This indicator is defined as drinking, on one occasion in the last 30 days (sometimes in the last two weeks) as much alcohol as to deliver a blood alcohol concentration (BAC) at the level of at least $80 \mathrm{mg} /$ $\mathrm{dl}$ or $0.8 \%$ [26]. That level of BAC is equivalent to drinking around five 'standard drinks' by a statistically typical adult male and around four by female. Standard drinks (containing each around $14 \mathrm{~g}$ of ethanol) are defined by amount of liquid of the commonly served portions of various alcoholic beverages.

Respondents from the Iława and Mokotów studies answered the question 'how much did you drink' by choosing 'I never drank' or one of the six remaining categories. Each of these de- o ostatni przypadek picia poszczególnych napojów alkoholowych: piwa, wina (w tym m.in. szampana, wina domowego) oraz wódki (i innych mocnych trunków jak whisky, gin czy koniak) - kiedy miał miejsce i ile wtedy wypili. Respondenci mogli wybrać kategorię nigdy nie piłem. Inne możliwe odpowiedzi na pytanie „kiedy?” obejmowały 8 kategorii: od przeszło rok temu do 1 do 4 dni temu. Na tej podstawie obliczano analizowane w niniejszej pracy wskaźniki, czyli „odsetki alkoholowych abstynentów” oraz „odsetki pijących alkohol w ciągu ostatnich 30 dni”. Pojęcie abstynencji zdefiniowano, za innymi polskimi badaczami, jako „niepicie żadnego napoju alkoholowego w okresie ostatnich 12 miesięcy, bezpośrednio poprzedzających moment badania” [25: 7].

W ankiecie ESPAD zastosowano inny, bardziej powszechny typ pytań o częstość picia alkoholu w okresie ostatnich 12 miesięcy i ostatnich 30 dni: „Ile razy (jeśli w ogóle) zdarzyło Ci się pić jakiś napój alkoholowy, tzn. piwo, wino, wódkę lub inny napój spirytusowy?". Pomimo różnicy w sformułowaniu pytań możliwe było obliczenie analogicznych wskaźników picia alkoholu, jak w badaniach iławskich i mokotowskich.

\section{Upijanie się (binge drinking)}

We wszystkich trzech porównywanych projektach badawczych analizowany jest wskaźnik dotyczący epizodów upijania się, nazywany w krajach anglosaskich binge drinking. Jest to główny wskaźnik intensywności picia alkoholu (drinking levels), polecany do stosowania $\mathrm{w}$ badaniach populacyjnych przez instytucje znaczące dla federalnej polityki zdrowotnej w USA, takie jak National Institute on Alcohol Abuse and Alcoholism (NIAAA) oraz Substance Abuse and Mental Health Services Administration (SAMHSA). Wskaźnik ten jest definiowany jako wypicie przy jednej okazji, w ostatnich 30 dniach (czasem ostatnich dwóch tygodniach) takiej ilości alkoholu, która daje jego stężenie we krwi (blood alcohol concentration - BAC) na poziomie co najmniej $80 \mathrm{mg} / \mathrm{dl}$, czyli 0,8\%o [26]. Taki poziom BAC ma odpowiadać wypiciu przez statystycznego dorosłego mężczyznę około pięciu „standardowych drinków”, a przez kobietę - około czterech. Standardowe drinki (zawierające każdy około $14 \mathrm{~g}$ etanolu) określane są przez podane objętości zwykle serwowanych porcji różnych napojów alkoholowych.

Respondenci z badań iławskich i mokotowskich w odpowiedzi na pytanie: „Ile wtedy wypiłeś?”, 
scribed the drinking of a definite number of measures appropriate to a given type of liquor as are usually served and in the appropriate size stated in millilitres. So in the case of beer, the basic size was a $500 \mathrm{ml}$ bottle, for wine it was a glass of $200 \mathrm{ml}$ and for vodka a large shot of $50 \mathrm{ml}$. It was on this basis that the Mokotów and Iława studies defined the binge-drinking indicator as the drinking on one occasion of at least three measures of beer, wine or vodka in the period of 30 days prior to the study. Assuming that the average ethanol content of beer at $5 \%$, wine at $10 \%$ and vodka at $40 \%$, it may be reckoned that the above-defined three measures are equivalent to the consumption of at least $60 \mathrm{ml}$ of pure ethyl alcohol.

Up to now, students' gender and body weight were not included in the definition of binge-drinking in the Mokotów and Iława studies. The same amount of consumed ethanol, depending on the above factors may give an entirely different level of organism intoxication understood as blood alcohol concentration. In order to verify this, we estimated the BAC level for hypothetical average 15 -year-old students using the Widmark formula [27-31]:

$\mathrm{BAC}[\% \mathrm{o}]=\mathrm{A}[\mathrm{g}] /(\mathrm{W}[\mathrm{kg}]$ * $\mathrm{r})-\beta \mathrm{t}[\% \mathrm{o}]$ where: $\mathrm{A}$ - the amount of consumed ethanol [ml] multiplied by its density $-0.789 \mathrm{~g} / \mathrm{ml}$

$\mathrm{W}$ - body weight in kilogrammes

$\mathrm{r}$ - reduction coefficient (Widmark factor) taking into account the proportions of water mass in the organism to total body mass and water content in the blood - that is approximately 0.68 for boys and 0.55 for girls

$\beta \mathrm{t}$ - amount of alcohol eliminated from the organism in an hour multiplied by the number of hours since the first drink

In calculating the average student body defined on the basis of Polish centile norms and values for the $50^{\text {th }}$ centile, separately for girls and boys with an average age of 15.5 years [32]. According to the NIAAA definition, it was found that the time of alcohol consumption was two hours. The coefficient of alcohol elimination $\beta$ was estimated at around $0.15 \mathrm{~g} / \mathrm{l} / \mathrm{h}$ [28: 13]. With the above assumptions and three measures of consumed alcohol (60 $\mathrm{ml}$ of ethanol) the estimated level of BAC intoxication was $0.83 \%$ or boys and $1.26 \%$ for girls. This showed that while the indicator was adequate for boys, it required correction for girls. wybierali nigdy nie piłem lub jedną z sześciu pozostałych kategorii. Każda z nich opisywała wypicie określonej liczby miar, właściwych dla danego trunku, tak jak zwykle są serwowane oraz w odpowiadającej im objętości podanej w mililitrach. I tak w przypadku piwa podstawową miarą była butelka (500 ml), dla wina „lampka” (200 ml) i dla wódki duży kieliszek $(50 \mathrm{ml})$. $\mathrm{Na}$ tej podstawie $\mathrm{w}$ badaniach mokotowskich i iławskich od wielu lat definiowano wskaźnik upijania się (binge drinking) jako wypicie w okresie 30 dni poprzedzających badania, przy jednej okazji co najmniej trzech miar - piwa, wina lub wódki. Zakładając przeciętną zawartość etanolu w piwie na $5 \%$, w winie na $10 \%$ i w wódce na $40 \%$, można obliczyć, że wyżej określone trzy miary odpowiadają konsumpcji co najmniej $60 \mathrm{ml}$ czystego alkoholu etylowego (etanolu).

Do tej pory w badaniach mokotowskich i iławskich, definiując upijanie się (binge drinking), nie uwzględniano płci i masy ciała uczniów. Ta sama ilość wypitego etanolu, w zależności od powyższych czynników, może dawać zupełnie różne poziomy intoksykacji organizmu, rozumianej jako poziom koncentracji alkoholu we krwi (BAC). Aby to zweryfikować, oszacowano poziom BAC dla hipotetycznych, przeciętnych uczniów i uczennic klas III gimnazjum, wykorzystując wzór E. Widmarka [27-31]: $\mathrm{BAC}[\% \mathrm{o}]=\mathrm{A}[\mathrm{g}] /(\mathrm{W}[\mathrm{kg}] * \mathrm{r})-\beta \mathrm{t}[\% \mathrm{o}]$ gdzie: A - ilość wypitego etanolu [ml] pomnożona przez jego gęstość $(0,789 \mathrm{~g} / \mathrm{ml})$

$\mathrm{W}$ - masa ciała w kilogramach

r - współczynnik redukcji (Widmark factor) uwzględniający proporcję masy wody w organizmie do całkowitej masy ciała oraz zawartość wody we krwi, który wynosi w przybliżeniu 0,68 dla chłopców i 0,55 dla dziewcząt

$\beta \mathrm{t}$ - ilość alkoholu eliminowana z organizmu w ciągu godziny pomnożona przez liczbę godzin upływających od momentu rozpoczęcia konsumpcji alkoholu

W obliczeniach masę ciała przeciętnego ucznia określono na podstawie polskich norm centylowych i wartości dla 50. centyla, osobno dla dziewcząt i chłopców, przy średniej wieku 15,5 roku [32]. Zgodnie z definicją NIAAA założono, że czas konsumpcji alkoholu wynosił dwie godziny. Współczynnik eliminacji alkoholu $\beta$ oszacowano na około $0,15 \mathrm{~g} / \mathrm{l} / \mathrm{h}$ [28: 13]. Przy powyższych założeniach i trzech porcjach wypitego alkoholu $(60 \mathrm{ml}$ etanolu) oszacowany $\mathrm{w}$ obliczeniach poziom intoksykacji BAC wyniósł: dla chłopców 0,83\%o i dla 
It was accepted that for girls the consumption of two alcoholic measures, that is at least $40 \mathrm{ml}$ of ethanol, was appropriate for BAC intoxication at around $0.74 \%$. Following the coefficient correction, the BAC values for boys and girls are similar and close to the definition of binge drinking value $-0.8 \%$. This confirms the validity of the corrected indicator in the structural aspect. It was also verified if the corrected indicator may be regarded as valid in the correlational aspect. Taking advantage of data from five Iława study editions, we compared the percentages of drunk students during the last 30 days provided by the corrected binge drinking indicator together with the subjective indicator of drunkenness, in other words according to the respondents own assessment. As it turned out, in the four study editions the value of both indicators did not vary significantly with only in the 2005 study the differences being statistically significant (McNemar's chi-square $=7.683$; $p=0.006$ ).

The indicator known as binge drinking is also analysed in the ESPAD studies. It was constructed on the basis of answers to the survey question 'Think of the last 30 days. How many times (if at all) have you drunk five or more «drinks» in a row in that time? («drink» here means a glass of wine, a bottle of beer, a small shot of vodka or other liquor or glass of low-percentage cocktail)'. The term 'low-percentage' was not defined, neither was the size of the alcoholic beverage portions, i.e. the 'small shot' of vodka or the 'glass' of wine. Apart from that, the indicator was not differentiated as regards gender. One can therefore expect differences in the indicator levels in our studies and ESPAD caused by differences in the definition of standard portions of alcohol (or rather due to a lack of sufficient precision of definition).

\section{Data analysis}

The results of the Mokotów studies are calculated for filtered data without considering older students who had repeated a class. Meanwhile, in the reports of the Iława studies and ESPAD, the results are for the whole studied sample without this kind of exception. Therefore, we calculated the values for the Mokotów study indicators including the older students who had repeated a year.

The percentage indicators were calculated in relation to the number of persons providing cer- dziewcząt - 1,26\%o. Wynika stąd, że wskaźnik jest adekwatny dla chłopców, a w przypadku dziewcząt wymaga korekty. Przyjęto więc dla dziewcząt konsumpcję dwóch porcji napoju alkoholowego, czyli co najmniej $40 \mathrm{ml}$ etanolu i obliczono, że taka ilość odpowiada intoksykacji (BAC) na poziomie około $0,74 \%$. Po skorygowaniu wskaźnika, wartości BAC są podobne dla dziewcząt i chłopców i bliskie definicyjnej wartości $0,8 \%$ dla binge drinking. Potwierdza to trafność skorygowanego wskaźnika w aspekcie strukturalnym. Sprawdzono także, czy skorygowany wskaźnik można uznać za trafny w aspekcie korelacyjnym. Wykorzystując dane $\mathrm{z}$ pięciu edycji badań iławskich, porównano odsetki upijających się uczniów w ostatnich 30 dniach, jakie dawał skorygowany wskaźnik binge drinking oraz subiektywny wskaźnik upijania się, czyli według własnej oceny badanych. Okazało się, że w czterech edycjach badań wartości obu wskaźników nie różniły się znacząco, a jedynie w badaniach z 2005 r. różnice były istotne statystycznie (chi-kwadrat McNemara $=7,683 ; p=0,006$ ).

W badaniach ESPAD także analizowany jest wskaźnik nazywany binge drinking. Skonstruowano go na podstawie odpowiedzi na pytanie ankietowe: „Pomyśl o ostatnich 30 dniach. Ile razy (jeśli w ogóle) wypiłeś pięć lub więcej «drinków» Z rzędu? («Drink» oznacza tu kieliszek wina, butelkę piwa, mały kieliszek wódki lub innego napoju spirytusowego albo szklankę niskoprocentowego koktajlu)". Nie zdefiniowano przy tym pojęcia "niskoprocentowy” i nie określono liczbowo pojemności porcji napojów alkoholowych - „małego kieliszka” wódki czy „kieliszka" wina. Ponadto nie różnicowano wskaźnika pod względem płci. Można spodziewać się rozbieżności w poziomach wskaźników w naszych badaniach i ESPAD spowodowanych przez różnice definicyjne standardowych porcji alkoholu (czy też przez brak dostatecznej precyzji w definicjach).

\section{Analiza danych}

Wyniki badań mokotowskich obliczane są dla danych filtrowanych, z pominięciem uczniów starszych rocznikiem, „drugorocznych”. Tymczasem w raportach $\mathrm{z}$ badań iławskich i ESPAD podaje się wyniki dla całej badanej próby, bez tego rodzaju wyłączeń. $\mathrm{Z}$ tego powodu przeliczono wartości wskaźników dla badań mokotowskich z uwzględnieniem uczniów „drugorocznych”.

Wskaźniki procentowe obliczano, odnosząc liczbę osób udzielających określonej odpowiedzi 
tain answers to the total of the studied group (or subgroup) together with lacking data. The results for male and female subgroups were not presented for two reasons: for simplification and greater clarity of compared results of various studies and as in the last edition of the Iława studies there was a lack of significant difference of indicator levels as regards gender.

Differences in the indicator values between particular Iława study editions were analysed using chi-square tests. Therefore, in the discussion of results, the terms 'increase' or 'decrease' usually mean statistically significant changes, and the term 'small' rise or fall refers to statistically insignificant changes.

In the analysis of the validity of the binge-drinking indicator, we applied McNemar's chi-square test variant for dependent groups.

The statistics package SPSS 15.0 was employed for calculation of results.

\section{- Results}

\section{Cigarette smoking}

The percentage of 15 year-old Iława's school students who currently smoke cigarettes has clearly varied over the course of the last several years. As Figure 1 demonstrates, first there was a period of marked falls from $34 \%$ to $22 \%$ and then between $2005-2015$ a period of growth to $37 \%$ and in the last years a new fall to $26 \%$.

Data from the last study edition indicates a large similarity of prevalence of current cigarette smoking among Iława and Warsaw students and the national sample as well. In the case of the Ilawa studies and the ESPAD national study, even identical percentages of cigarette smoking students were gained; i.e $26.4 \%$. There was a certain difference with respect to the growth dynamic of the Ilawa study indicator (15.5\% growth in 2005-2010) compared to the ESPAD studies (only 8\% in 2007-2011).

The other indicator - daily cigarette smoking - changed over time in similar fashion as described above current smoking (Fig. 2). In the Iława studies, at first we observed a fall in the indicator values, then a rise followed by another fall with a stabilisation at around $12 \%$ in recent years. The line joining all the measurement points is multinomial in shape and is analogous to the line illustrating changes in the indicator do całkowitej liczebności badanej grupy (lub podgrupy), wraz z brakami danych. Nie prezentowano wyników dla podgrup kobiet i mężczyzn z dwóch powodów: dla uproszczenia i większej czytelności porównań wyników różnych badań oraz ponieważ w ostatniej edycji badań iławskich stwierdzono brak istotnych różnic $\mathrm{w}$ poziomie wskaźników ze względu na płeć.

Różnice wartości wskaźników między poszczególnymi edycjami badań iławskich analizowano, wykorzystując testy chi-kwadrat. W związku z tym w opisie wyników określenia „wzrost” lub „spadek" oznaczają z reguły istotne statystycznie zmiany, a „nieznaczny” czy „nieznaczący” wzrost lub spadek oznacza zmiany nieistotne statystycznie.

W analizach trafności wskaźnika upijania się (binge drinking) zastosowano wariant testu dla grup zależnych - chi-kwadrat McNemara.

Do obliczeń wykorzystano pakiet statystyczny SPSS 15.0.

\section{- WYNIKI}

\section{Palenie papierosów}

Odsetki 15-letnich uczniów iławskich gimnazjów aktualnie palących papierosy podlegały wyraźnym wahaniom $\mathrm{w}$ ciągu ostatnich kilkunastu lat. Jak pokazano na rycinie 1 , najpierw był okres znaczącego spadku z 34\% do 22\%, następnie w latach 2005-2010 okres wzrostu do 37\% i w ostatnich latach ponowny spadek do $26 \%$.

Dane $\mathrm{z}$ ostatnich edycji badań wskazują na duże podobieństwo rozpowszechnienia bieżącego palenia papierosów wśród młodzieży iławskiej, warszawskiej oraz w próbie ogólnopolskiej. W przypadku badań iławskich i ogólnopolskich badań ESPAD uzyskano nawet identyczne odsetki uczniów aktualnie palących papierosy, tj. 26,4\%. Pewna różnica dotyczyła większej dynamiki wzrostu wartości wskaźnika w badaniach iławskich (w latach 2005-2010 wzrost o 15,5 punktów procentowych) niż w badaniach ESPAD (w latach 20072011 wzrost tylko o 8 punktów procentowych).

Drugi wskaźnik, codzienne palenie papierosów, zmieniał się w czasie podobnie jak opisane wyżej bieżące palenie (ryc. 2). W badaniach iławskich obserwujemy początkowo spadek wartości wskaźnika, a następnie wzrost i ponowny spadek, ze stabilizacją na poziomie około $12 \% \mathrm{w}$ ostatnich latach. Linia łącząca poszczególne punkty pomiaru ma kształt wielomianowy, analogiczny jak 


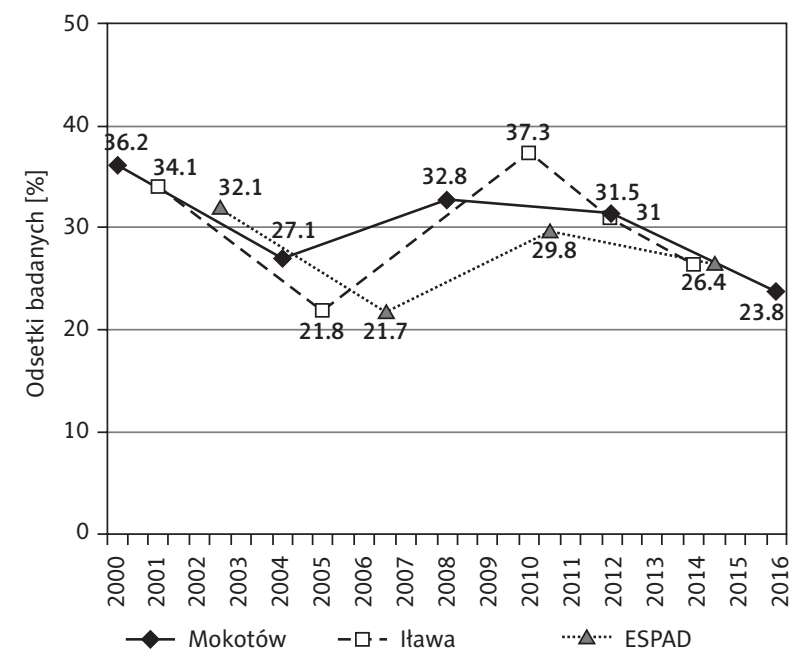

Figure 1. Current cigarette smoking. Comparison of trends among 15-year-old students observed in different studies: Iława, Mokotów and ESPAD

Rycina 1. Palący papierosy. Porównanie trendów wśród uczniów klas III gimnazjum, obserwowanych w badaniach iławskich, mokotowskich i ESPAD

for the ESPAD studies, though it is located a few percentage points lower on the chart. This means that the proportion of daily smokers in the Iława studies are systematically somewhat lower compared to those for young people in the national studies. In the school year 2014/2015 these were $11.7 \%$ and $14.5 \%$ respectively. The changes in this indicator in the Mokotów studies were somewhat different as there was a systematic fall in the daily smokers percentage from $18.4 \%$ in 2000 to $6.4 \%$ in 2016 . The only exception was a minimal, one per cent rise in the indicator between 2008 and 2012 .

\section{Drinking alcohol}

In the Iława studies we observe a basic rising tendency for the number of alcohol abstainers (not drinking in the last year) from $18 \%$ in 2001 to $30 \%$ in 2014 , interrupted by a period of slight fall in 2005-2010 (Fig. 3). These changes are very similar to the national sample, in which the abstinence indicator rose between 1999 and 2015 by around $10 \%$ to reach levels close to the Iława study results (28\%) in 2015.

The changes in the abstinence indicator for the Mokotów studies were different. The shape of trend curve may be described with the aid of an exponential function. At first, in 2000-2008, the abstinence indicator remained at a simi-

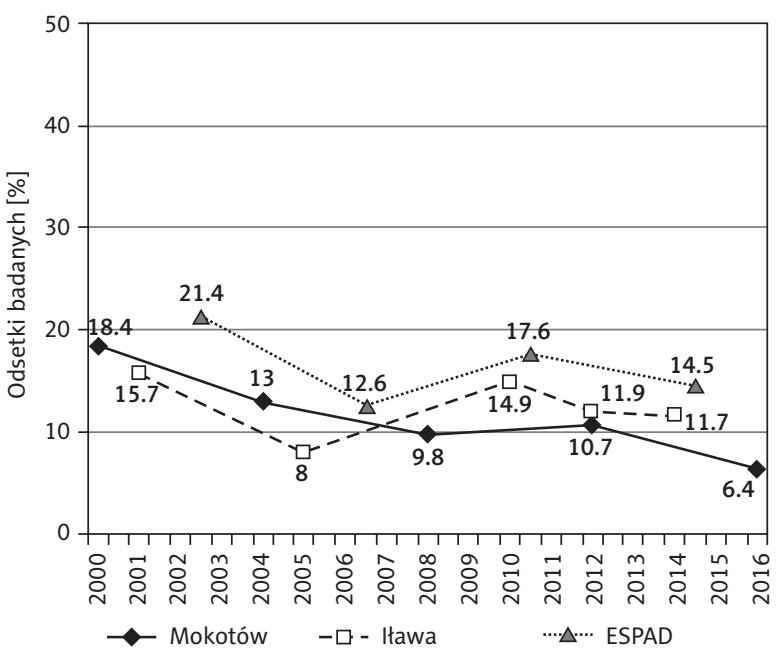

Figure 2. Everyday cigarette smoking. Comparison of trends among 15-year-old students observed in different studies: Iława, Mokotów and ESPAD

Rycina 2. Codzienne palenie papierosów. Porównanie trendów wśród uczniów klas III gimnazjum, obserwowanych w badaniach iławskich, mokotowskich i ESPAD

linia obrazująca zmiany wskaźnika w badaniach ESPAD, ale znajduje się kilka punktów procentowych niżej na wykresie. Oznacza to, że odsetki osób palących codziennie w badaniach iławskich są systematycznie nieco niższe $\mathrm{w}$ porównaniu z odsetkami młodzieży w badaniach ogólnopolskich. W roku szkolnym 2014/2015 wynosiły one odpowiednio: $11,7 \%$ i 14,5\%. Zmiany tego wskaźnika $\mathrm{w}$ badaniach mokotowskich przebiegały nieco inaczej - następowały systematyczne spadki odsetka codziennie palacych: z 18,4\% w 2000 r. do 6,4\% w 2016 r. Wyjątkiem był minimalny, jednoprocentowy wzrost wartości wskaźnika między 2008 i 2012 r.

\section{Picie alkoholu}

W badaniach iławskich obserwujemy zasadniczo tendencję wzrostową odsetka alkoholowych abstynentów (niepijący w ostatnim roku) - z 18\% w 2001 r. do 30\% w 2014 r., przerwaną okresem nieznacznego spadku w latach 2005-2010 (ryc. 3). Zmiany te są bardzo podobne jak w próbie ogólnopolskiej, w której wskaźnik abstynencji wzrósł w latach 1999-2015 o około 10 punktów procentowych i osiągnął w 2015 r. wartość zbliżoną do wyniku z badań iławskich (28\%).

Zmiany wartości wskaźnika abstynencji w badaniach mokotowskich przebiegają inaczej. Kształt krzywej trendu można by opisać za pomocą funkcji wykładniczej. Początkowo, w latach 2000-2008, 


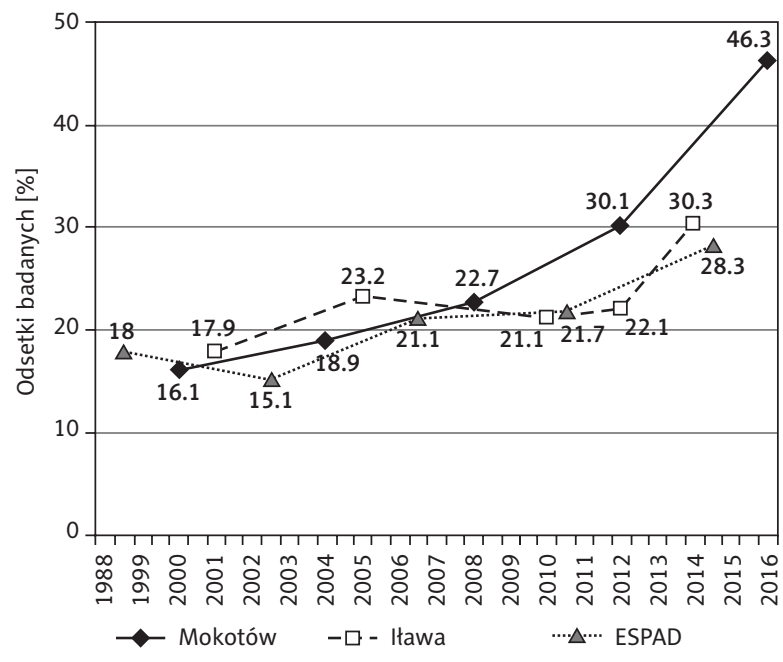

Figure 3. Abstainers (didn't drink alcohol in the past year). Comparison of trends among 15-year-old students observed in different studies: Iława, Mokotów and ESPAD Rycina 3. Abstynenci (niepijący alkoholu w ostatnim roku). Porównanie trendów wśród uczniów klas III gimnazjum, obserwowanych w badaniach iławskich, mokotowskich i ESPAD

lar level to remaining studies and gradually increased to $23 \%$ in 2008 . Since then, the number of abstainers doubled in Mokotów and in 2016 reached $46 \%$, clearly exceeding the abstinence levels shown among young people in Iława and the national sample.

A further indicator is drinking any kind of alcohol in the last 30 days (Fig. 4). In the Iława studies at first between 2001 and 2005 the indicator values were stable at $42-43 \%$. These were clearly lower over this period compared to the indicator values from the Mokotów studies (by around $8 \%$ ) and very different to the national levels, which were lower by around $20 \%$. In the subsequent time period of 2005 to 2010 , there was a dynamic rise in the indicator for the Iława studies to $52 \%$ while in the remaining studies this was a period of stabilisation and the start of marked falls in the Mokotów studies. Between 2010 and 2014, the direction of trends converges again as we note a dynamic decrease in the number of drinking young people in the last 30 days in all studies. However, the fall in the Iława studies is more dynamic and reached almost $20 \%$, with $14 \%$ in the Mokotów studies and almost $10 \%$ in ESPAD. Therefore, the indicator values of the Iława studies and ESPAD diverges with in the last edition of both

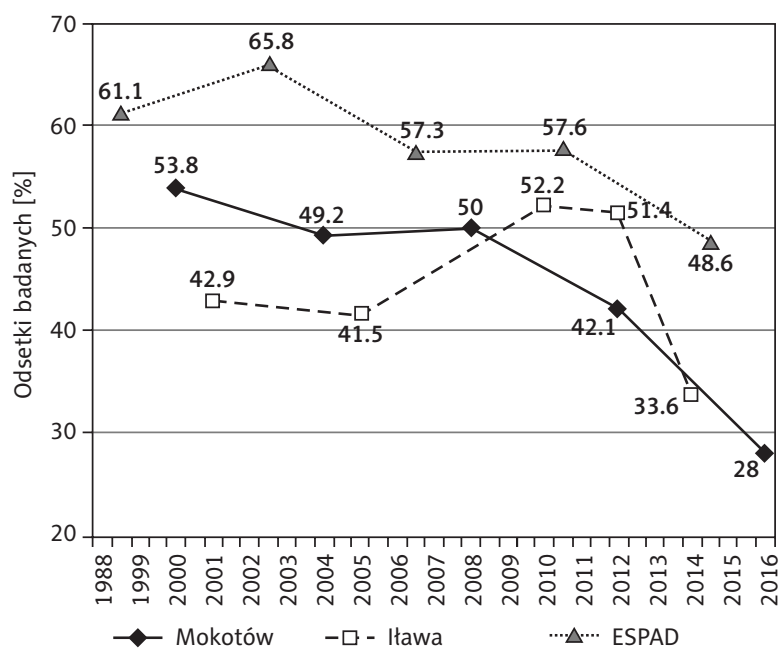

Figure 4. Any alcohol use in the past 30 days. Comparison of trends among 15-year-old students observed in different studies: Iława, Mokotów and ESPAD Rycina 4. Picie jakiegokolwiek alkoholu w ostatnich 30 dniach. Porównanie trendów wśród uczniów klas III gimnazjum, obserwowanych w badaniach iławskich, mokotowskich i ESPAD

wskaźnik abstynencji utrzymywał się na podobnym poziomie jak w pozostałych badaniach, stopniowo zwiększając się do 23\% w 2008 r. Od tego czasu odsetek abstynentów na Mokotowie zwiększył się dwukrotnie i w 2016 r. osiągnął 46\%, przewyższając wyraźnie odsetki abstynentów wśród młodzieży iławskiej i z próby ogólnopolskiej.

Kolejny wskaźnik to picie jakiegokolwiek napoju alkoholowego w ostatnich 30 dniach (ryc. 4). W badaniach iławskich początkowo, między 2001 a 2005 r., wartości wskaźników utrzymywały się na stabilnym poziomie $42-43 \%$. W tym okresie były wyraźnie niższe w porównaniu $\mathrm{z}$ wartościami wskaźników z badań mokotowskich (o około 8 punktów procentowych) i bardzo odbiegały od ogólnopolskich (niższe o około 20 punktów procentowych). W następnym przedziale czasu (2005-2010) następuje dynamiczny wzrost wartości wskaźnika w badaniach iławskich do $52 \%$, podczas gdy w pozostałych badaniach jest to okres stabilizacji wskaźników i początek wyraźnych spadków w badaniach mokotowskich. W latach 2010-2014 kierunki trendów stają się znowu zbieżne - we wszystkich badaniach obserwujemy dynamiczne spadki odsetków młodzieży pijącej alkohol w ostatnich 30 dniach. Przy czym spadek w badaniach iławskich jest najbardziej dynamiczny i sięga blisko 20 punktów procentowych, w badaniach mokotowskich 14 , a w badaniach 


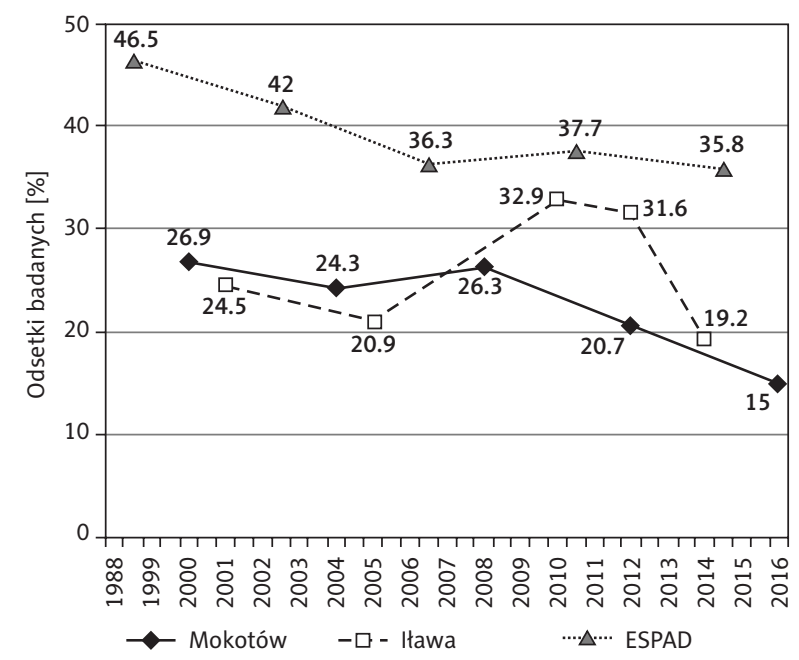

Figure 5. Binge drinking in the past 30 days. Comparison of trends among 15-year-old students observed in different studies: Iława, Mokotów and ESPAD

Rycina 5. Upicie się w ostatnich 30 dniach, wskaźnik obiektywny. Porównanie trendów wśród uczniów klas III gimnazjum, obserwowanych w badaniach iławskich, mokotowskich i ESPAD

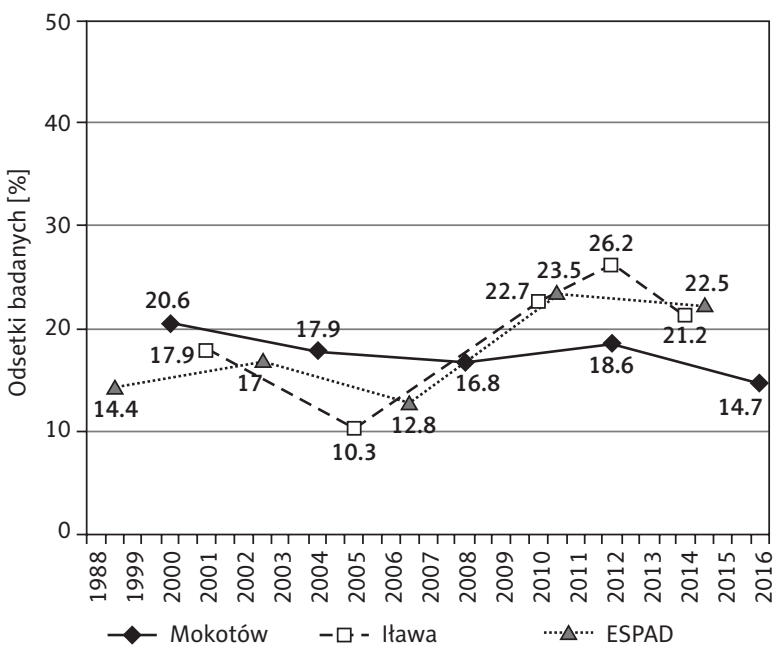

Figure 6. Any drug use at least once in the past year. Comparison of trends among 15-year-old students observed in different studies: Itawa, Mokotów and ESPAD (ESPAD - indicator values were estimated based on marijuana use data)

Rycina 6. Używanie jakichkolwiek środków narkotyzujących co najmniej raz w ostatnim roku. Porównanie trendów wśród uczniów klas III gimnazjum, obserwowanych w badaniach iławskich, mokotowskich i ESPAD (ESPAD - wartości wskaźnika oszacowano na podstawie danych dotyczących używania marihuany)

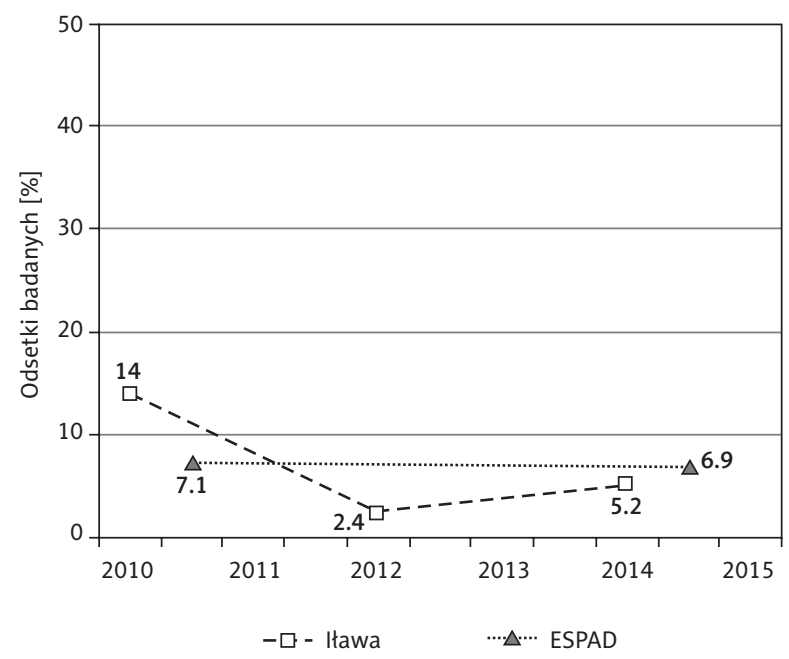

Figure 7. Any designer drug use at least once in the past year. Comparison of short-term trends among 15-year-old students observed in Itawa and ESPAD study

Rycina 7. Używanie dopalaczy co najmniej raz w ostatnim roku. Porównanie krótkoterminowych trendów wśród uczniów klas III gimnazjum, obserwowanych w badaniach iławskich i ESPAD 
studies from the school year 2014-2015 to 34\% and $49 \%$ respectively.

Binge drinking in the last 30 days

The binge-drinking indicator value among the Iława school students fell slightly from 25\% to $21 \%$ in $2001-2005$, and then rose significantly in 2010 to $33 \%$ to fall back to $19 \%$ in 2014 (Fig. $5)$. The changes in the indicator were quite similar in the Mokotów studies up to 2008, after which, instead of further growth as in the Iława studies, we observed a fall in the values from $26 \%$ to $15 \%$ in 2016. So the trends in both studies are similar with the exception of 2008 to 2012 when they were divergent.

The binge-drinking indicator applied in the ESPAD research (with a different structure to ours) reveals a higher estimate for binge-drinking school students compared to the other studies. These differences were considerable and reached $20 \%$. In 1999-2007, the indicator values fell systematically from $47 \%$ to $36 \%$ and then remained stable at that level until 2015.

\section{Drug use}

As shown in Fig. 6, the lines joining the measurement points converge in the Iława studies and ESPAD. This means that in both studies the number of students using drugs at least once in the last year is almost identical over several years. In the Iława studies the start indicator value was around $18 \%$ in 2001 , then a fall to $10 \%$ in 2005 followed by a very clear rise to $26 \%$ in 2012 and a slight fall to around $21 \%$ in 2014 .

The changes in the indicator values were different in the Mokotów studies. Up to 2004, the number of users was slightly higher than in the Iława studies but these equalled out in 2008 at around $17 \%$ and only to then rise slightly to reach $15 \%$ in the last study edition.

\section{Designer drugs use}

According to the Iława studies from the end of $2010,14 \%$ of 15 year-old school students had used designer drugs at least once in the past year (Fig. 7). This number fell to $2.4 \%$ in 2012 followed by a slight rise to $5.2 \%$ at the end of 2014 . ESPAD data, which included only two readings from the spring of 2011 and 2015, indicate a stabilisation of designer drug consumers during the last
ESPAD to blisko 10 punktów. Skutkiem tego wartości wskaźników w badaniach iławskich i ESPAD oddalają się i w ostatniej edycji obu badań z roku szkolnego 2014/2015 wynoszą odpowiednio: około 34\% i 49\%.

\section{Upijanie się w ostatnich 30 dniach}

Wśród iławskiej młodzieży wartość wskaźnika upijania się (binge drinking) w latach 2001-2005 nieznacznie spadła z $25 \%$ do $21 \%$, a następnie znacząco wzrosła w 2010 r. do 33\%, by w 2014 r. spaść do $19 \%$ (ryc. 5). Dość podobnie przebiegały zmiany wskaźnika w badaniach mokotowskich do 2008 r., po czym, zamiast dalszego wzrostu jak w badaniach iławskich, obserwujemy spadek wartości wskaźnika z 26\% do $15 \%$ w 2016 r. Tak więc trendy w obu badaniach są zbliżone, $\mathrm{z}$ wyjątkiem okresu 2008-2012, kiedy podążyły w różnych kierunkach.

Wskaźnik binge drinking stosowany $\mathrm{w}$ badaniach ESPAD (inaczej skonstruowany niż w naszych badaniach) dawał wyższe oszacowania odsetków upijającej się młodzieży w porównaniu z pozostałymi badaniami. Różnice te były znaczne i sięgały 20 punktów procentowych. W latach 1999-2007 wartości wskaźnika systematycznie spadały - z $47 \%$ do $36 \%$, a następnie pozostawały stabilne na tym poziomie aż do $2015 \mathrm{r}$.

\section{Używanie narkotyków}

Jak obrazuje rycina 6 , linie łączące punkty pomiaru w badaniach iławskich i ESPAD pokrywają się. Oznacza to, że w obu badaniach odsetki uczniów używających narkotyków przynajmniej raz w ostatnim roku są na przestrzeni kilkunastu lat niemal identyczne. W badaniach iławskich, począwszy od około 18\% używających w 2001 r. i spadku wartości wskaźnika do 10\% w 2005 r., obserwujemy bardzo wyraźny wzrost do $26 \%$ w 2012 r. i następnie nieznaczny spadek do około $21 \%$ w 2014 r.

Inaczej przebiegały zmiany wartości tego wskaźnika w badaniach mokotowskich. Do 2004 r. odsetki używających były nieco wyższe niż w badaniach iławskich, ale wyrównały się w 2008 r. na poziomie około $17 \%$, aby następnie po nieznacznym wzroście osiągnąć w ostatniej edycji badań poziom $15 \%$.

\section{Używanie dopalaczy}

Według danych z badań iławskich, w końcu $2010 \mathrm{r}$. 14\% gimnazjalistów używało dopalaczy przynajmniej raz w ostatnim roku (ryc. 7). Odsetek ten spadł do 2,4\% w 2012 r. i następnie wzrósł nieznacznie do 5,2\% 
year at the level of 7\%. A comparison of the results of the two studies only reveals that in the school year 2014/2015, the prevalence of designer drug use among 15 year-old Iława school students was similar to the national sample. However, it is difficult to compare the trends of both studies as there is a lack of an ESPAD reading for 2010 from the time of greatest designer drug availability and also no reading for 2012 when the availability of these substances was probably strongly limited.

\section{- Discussion}

The last edition of the Iława studies from 2014 brought very favourable results revealing falls in the majority of the analysed indicators of psychoactive substance use in the population of 15 yearolds. Over the last years the number of school students smoking cigarettes fell to $23 \%$, those drinking alcohol to $34 \%$ and those binge-drinking in the last 30 days to $19 \%$ while the number of alcohol abstainers, that is persons not drinking alcohol in the last year, increased to $30 \%$. However, it ought to be borne in mind that over this period the consumption of designer drugs did increase slightly from $2.4 \%$ to $5.2 \%$ and the indicator of other psychoactive substance use remains at quite a high level at $21 \%$ following a big rise in 2005-2010.

Summing up the conducted analysis, we can find the very large similarity of trends observed among Iława school students and that in the national sample. This concerns the prevalence of cigarette smoking including daily smoking, the percentage of alcohol abstainers and drug consumers in the last year. In the last case the lines joining the measurement points are so well aligned that it would seem the Iława results could be treated as a very good predictor of the prevalence of these substances on the national scale among 15 to 16 year-olds. However, the results of the Mokotów studies from 2012 diverged from the Iława studies and ESPAD, indicating clearly lower prevalence of drugs use and daily cigarette smoking and a higher number of alcohol abstainers.

In the case of drinking alcohol in the last 30 days and binge drinking over the same period, the results of the Iława studies clearly diverged from that of the ESPAD research and the indica- w końcu 2014 r. Dane z ESPAD, obejmujące tylko dwa pomiary - z wiosny 2011 i 2015 r. wskazują na utrzymywanie się odsetka konsumentów używających dopalaczy w ciągu ostatniego roku na poziomie 7\%. Porównując wyniki obu badań, można jedynie stwierdzić, że w roku szkolnym 2014/2015 rozpowszechnienie używania dopalaczy wśród gimnazjalistów iławskich było podobne jak w próbie ogólnopolskiej. Trudno natomiast porównać trendy w obu badaniach, ponieważ w ESPAD brak jest pomiaru w 2010 r. z okresu największej dostępności dopalaczy oraz nie ma pomiarów z 2012 r. z okresu prawdopodobnie bardzo ograniczonej dostępności tych substancji.

\section{- OmóWIENIE}

Ostatnia edycja badań iławskich z 2014 r. przyniosła bardzo korzystne wyniki, pokazujące spadki większości analizowanych wskaźników używania substancji psychoaktywnych w populacji 15-letniej młodzieży. Na przestrzeni ostatnich lat zmniejszył się odsetek uczniów palących papierosy (do 23\%), pijących alkohol (do 34\%) i upijających się w ostatnich 30 dniach (do 19\%) oraz zwiększył odsetek alkoholowych abstynentów (do 30\%), czyli osób, które nie piły alkoholu w ostatnim roku. Należy jednak pamiętać, że nieco wzrosła w tym samym czasie konsumpcja dopalaczy (z 2,4\% do 5,2\%), a wskaźnik używania innych substancji psychoaktywnych, po dużym wzroście w okresie 2005-2010, nadal jest na dość wysokim poziomie (21\%).

Podsumowując przeprowadzone analizy, możemy stwierdzić bardzo duże podobieństwo trendów obserwowanych wśród młodzieży iławskiej do trendów w próbie ogólnopolskiej. Dotyczy to rozpowszechnienia palenia papierosów, w tym także palenia codziennego, odsetka alkoholowych abstynentów oraz odsetka konsumentów narkotyków w ostatnim roku. W tym ostatnim przypadku linie łączące punkty pomiaru pokrywają się tak dokładnie, że - jak się wydaje - wyniki badań iławskich można traktować jako bardzo dobry predyktor rozpowszechnienia tych substancji w skali ogólnopolskiej - wśród młodzieży 15-16-letniej. Natomiast wyniki badań mokotowskich od 2012 r. odbiegały od wyników badań iławskich i ESPAD, wskazując na wyraźnie niższe rozpowszechnienie używania narkotyków oraz codziennego palenia papierosów i na wyższy odsetek alkoholowych abstynentów.

W przypadku picia alkoholu $\mathrm{w}$ ciągu ostatnich 30 dni oraz upijania się (binge drinking) w tym okre- 
tors value for Iława school students were clearly lower over the several years of study. The Iława study trends concerning these indicators were closer to those of the Mokotów studies. Especially evident is the convergence in results for the last editions of both studies. The exception is the period 2008-2012 when the trends went off in different directions: the Iława studies noting a dynamic rise in the prevalence of frequent and binge drinking while in the Mokotów research these values fell. We would add that in this time values concerning the alcohol indicators in the national sample remained at a stable level. The above discrepancies may bear witness to existence of specific circumstances in Iława responsible for a period of temporary rising of alcohol indicators values.

Analysis of long-term trends indicates a dominant falling tendency for alcohol drinking and binge drinking observed in all three analysed research projects. However, in terms of drugs use and cigarette smoking what is visible is a constant fluctuation with periods of falling indicators values overlapping with rising trends. In the years 2008-2012 there was a large rise in the number of drug using students in the last year of around $15 \%$, which was observed in the Iława study and the national ESPAD sample but not noted in the Mokotów study.

It is possible to formulate the hypothesis that the rise in the indicators values for the use of various substances in 2008-2010 is due to the increased supply of designer drugs and their consumption by a significant group of school students.

It would seem that the results of the Ilawa studies concerning designer drug use reflect periodic changes in the availability of designer drugs in specialist shops. As described in the introduction, there was first a peak in designer drug availability in 2010 with 1400 shops in the country (including one in Iława) followed by their closure on the decision of the Chief Sanitary Inspectorate in the autumn of 2010. The Iława studies of the end of 2010 show $14 \%$ of school students using designer drugs last year followed by a fall of $2.4 \%$ in 2012 when these designer drug shops had already been closed for two years. It was only in 2013-2015 that the availability of designer drugs increased somewhat as some of the shops opened again and the national number exceeded 200. And this was reflected to a certain extent in sie, wyniki badań iławskich wyraźnie odbiegały od wyników badań ESPAD, a wartości wskaźników dla młodzieży iławskiej w kilkunastoletnim okresie były znacznie niższe. Trendy w badaniach iławskich, dotyczące tych wskaźników, były bardziej zbliżone do trendów w badaniach mokotowskich. Szczególnie widoczna jest zbieżność w wynikach ostatnich edycji obu badań. Wyjątek stanowi okres lat 2008-2012, kiedy to trendy podążały $\mathrm{w}$ różnych kierunkach: w badaniach iławskich odnotowano dynamiczny wzrost rozpowszechnienia częstego picia i upijania się, podczas gdy w badaniach mokotowskich wartości tych wskaźników spadały. Dodajmy, że w tym czasie w próbie ogólnopolskiej wartości wskaźników dotyczących alkoholu utrzymywały się na stabilnym poziomie. Powyższe rozbieżności mogą świadczyć o tym, że w Iławie lokalnie zaistniały jakieś szczególne okoliczności, odpowiadające za okresowy wzrost wartości wskaźników alkoholowych.

Analiza długoterminowych trendów wskazuje na dominujące tendencje spadkowe dotyczące picia alkoholu i upijania się, obserwowane we wszystkich trzech analizowanych projektach badawczych. Natomiast w zakresie używania narkotyków i palenia papierosów widoczna jest ciągła fluktuacja: okresy spadków wartości wskaźników przeplatane są okresami wzrostów. W latach 20082012 nastąpił duży, około 15-punktowy, wzrost odsetków uczniów używających narkotyków w ostatnim roku obserwowany w badaniach iławskich oraz w próbie ogólnopolskiej ESPAD, a nieodnotowany w badaniach mokotowskich.

Można sformułować hipotezę, że za wzrosty wartości wskaźników używania różnych substancji w latach 2008-2010 odpowiadała zwiększona dostępność dopalaczy i używanie ich przez znaczną część młodzieży.

Wydaje się, że w wynikach badań iławskich dotyczących używania dopalaczy znalazły odzwierciedlenie okresowe zmiany $\mathrm{w}$ dostępności dopalaczy w specjalnych sklepach. Jak opisano we wstępie, najpierw był szczyt dostępności dopalaczy w 2010 r. i 1400 sklepów w kraju (w tym jeden sklep w Iławie), po czym nastąpiło ich zamknięcie decyzją GIS (jesienią 2010). Badania iławskie z końca 2010 r. mówią o 14\% młodzieży używającej dopalaczy w ostatnim roku, a następnie o spadku tego odsetka do 2,4\% w 2012 r., kiedy sklepy z dopalaczami były od dwóch lat zamknięte. Dopiero w okresie 2013-2015 dostępność dopalaczy nieco się zwiększyła. Ponownie otwarto część sklepów, 
the Iława studies according to which the number of designer drug consumers slightly increased from $2.4 \%$ to $5.2 \%$ at the end of 2014 .

In this context, the results of ESPAD studies do not reveal any dynamic in the prevalence of designer drug use, though we are aware from other studies [24] that the changes were in fact severe. Everything indicates that the four-year breaks between subsequent ESPAD study editions were too long and prevented the capture of fast-moving changes. These changes where revealed in the Iława studies thanks to the planned time of study in 2010 coinciding with the period of greatest designer drug availability and furthermore additional studies were carried out in 2012.

The above circumstances justify the postulated tendency towards increasing the frequency of readings in periodically repeated population studies. One might suggest a two-year interval between successive study editions as a minimum. It is worth noting at this stage that large youth population studies in the USA like Monitoring the Future (MTF) [22] or National Survey on Drug Use and Health (NSDUH) [33] are carried out usually every year as are all the most important population studies in the USA described by SAMHSA [34]. We identified only one study (in Canada) at a regional level carried out systematically every two years, which monitors various aspects of youth mental health, including also psychoactive substance use [35].

Returning to the interpretation of the study results, the link between the legal availability of designer drugs and the prevalence of their use among school students is obvious. We therefore pose the question whether the increased use of designer drugs could have had a bearing on the rising indicators of other substance use observed between 2008 and 2012.

There is no doubt that this could have affected the rise in percentage of students confirming the use of drugs in the last year including marijuana. The reason is the fact that the most popular designer drug among consumers was synthetic cannabinoids sold in the form of dry herb mixtures for smoking soaked in psychoactive substances [18: 23]. As a consequence, consumers of these designer drugs, being conscious of their content ought to be defining themselves also as users of marijuana and drugs in general. których liczba w kraju przekroczyła 200. I znowu znalazło to pewne odzwierciedlenie w badaniach iławskich, według których odsetek konsumentów dopalaczy w końcu 2014 r. nieznacznie się zwiększył z 2,4\% do 5,2\%.

$\mathrm{Na}$ tym tle wyniki badań ESPAD nie pokazują żadnej dynamiki w rozpowszechnieniu używania dopalaczy, choć wiemy także z innych badań [24], że zmiany w rzeczywistości były gwałtowne. Wszystko wskazuje na to, że czteroletnie przerwy między kolejnymi edycjami badań ESPAD były zbyt długie i uniemożliwiły uchwycenie szybko następujących zmian. Zmiany te uchwycono w badaniach iławskich dzięki temu, że planowany termin badań w 2010 r. zbiegł się z okresem największej dostępności dopalaczy, a ponadto przeprowadzono dodatkowe badania w 2012 r.

Powyższe okoliczności uzasadniają postulat dążenia do zwiększenia częstotliwości pomiaru w powtarzanych okresowo badaniach populacyjnych. Jako minimum można by postulować interwał dwóch lat pomiędzy kolejnymi edycjami badań. Warto w tym miejscu zauważyć, że duże badania populacyjne młodzieży w USA, takie jak Monitoring the Future (MTF) [22] czy National Survey on Drug Use and Health (NSDUH) [33], realizowane są z reguły co roku, podobnie jak cała pula najważniejszych badań populacyjnych w USA, opisywanych przez SAMHSA [34]. Zidentyfikowano tylko jedno badanie (kanadyjskie) o zasięgu regionalnym, przeprowadzane systematycznie co dwa lata, monitorujące różne aspekty zdrowia psychicznego młodzieży, w tym także używanie substancji psychoaktywnych [35].

Wracając do interpretacji wyników badań, oczywisty jest związek pomiędzy dostępnością dopalaczy $\mathrm{w}$ legalnym handlu a rozpowszechnieniem ich używania wśród młodzieży. Postawmy więc pytanie, czy zwiększone używanie dopalaczy mogło wpłynąć na wzrost wartości wskaźników używania innych substancji, obserwowany w latach 2008-2012?

Niewątpliwie mogło to wpłynąć na wzrost odsetka uczniów potwierdzających używanie narkotyków w ostatnim roku, w tym także marihuany. Powodem jest fakt, że najpopularniejsze wśród konsumentów dopalaczy były syntetyczne kannabinoidy, sprzedawane w postaci nasączanych substancją psychoaktywną ziołowych mieszanek do palenia [18: 23]. W konsekwencji konsumenci takich dopalaczy, świadomi ich zawartości, powinni określać się w badaniach ankietowych również jako użytkownicy marihuany i ogólnie - narkotyków. 
This suggests the further question whether the rapid increase in drugs use could have had a bearing on increases in the use of cigarettes and alcohol? It is understood that the use of various substances is strongly correlated and the use of one often implies the use of others [36]. For this reason it is possible that the rapidly rising use of drugs could have influenced an increase in alcohol drinking and cigarette smoking. ESPAD research did not note an increased level of alcohol drinking in 2008-2012, while the Iława studies did observe rises of this kind. Perhaps what decided this difference were the local specifics linked to the crossing of a certain threshold of interest in designer drugs. In the light of accessible studies from 2010, the level of Iława 15 year-olds' interest in designer drugs was twice as high (14\% using designer drugs in the last year) than among their older 18-to-19-year-old counterparts from the national sample $(7.2 \%$ had used designer drugs in the last year) [18].

It is also worth taking into account why despite limitations in the supply of designer drugs, the Iława study continues to reveal high levels of drug use in 2012 and 2014. Similar results were gained in the ESPAD study in 2015. It would seem likely that school children abusing designer drugs, rather mainly synthetic cannabinoids, in the face of the rapid limitation of their availability towards the end of 2010, could have replaced them with phytocannabinoids, that is marijuana.

The above inquiries are of course purely hypothetical. The reveal a possible event scenario according to which a large supply and easy availability of designer drugs may bring consequences in the form of a clear and rather long-term rise in the prevalence of marijuana use and also a less long-term rise in cigarette smoking, alcohol drinking and binge drinking.

This paper suggests correction of the bingedrinking indicator to adjust it to gender, age and respondents' body weight. What is needed is a wider discussion amongst persons involved in youth population studies on the subject of standards for the binge-drinking reading. One could, for example, with greater precision estimate the level of intoxication taking into account individual data on age, body weight and height [30] instead of estimating the parameters for whole respondent subgroups. Despite many imperfections, the corrected binge-drinking in-
Nasuwa się kolejne pytanie: czy zwiększone skokowo używanie narkotyków mogło wpłynąć na zwiększenie używania papierosów i alkoholu? Wiadomo, że używanie różnych substancji jest ze sobą silnie skorelowane, a używanie jednej substancji często pociąga za sobą używanie innych [36]. Z tego powodu jest możliwe, że zwiększone skokowo używanie narkotyków mogło wpłynąć na zwiększenie używania papierosów i alkoholu. W badaniach ESPAD nie odnotowano zwiększonego poziomu picia alkoholu w latach 2008-2012, podczas gdy w badaniach iławskich takie wzrosty zaobserwowano. Być może zadecydowała o tym lokalna specyfika związana z przekroczeniem pewnego progu zainteresowania dopalaczami. W świetle dostępnych badań z 2010 r. poziom zainteresowania dopalaczami 15-letniej młodzieży w Iławie był dwukrotnie większy (14\% używających dopalaczy w ostatnim roku) niż wśród ich starszych, 18-19-letnich kolegów z próby ogólnopolskiej (7,2\% używających dopalaczy w ostatnim roku) [18].

Warto zwrócić jeszcze uwagę na jedną kwestię: dlaczego, mimo ograniczenia podaży dopalaczy, używanie narkotyków w badaniach iławskich utrzymywało się nadal (w roku 2012 i 2014) na wysokim poziomie? Podobne wyniki uzyskano w badaniach ESPAD z 2015 r. Wydaje się prawdopodobne, że młodzież używająca dopalaczy, a więc głównie syntetycznych kannabinoidów, wobec gwałtownego ograniczenia ich dostępności w sklepach pod koniec 2010 r., mogła zastąpić je, używając kannabinoidów pochodzenia roślinnego, czyli marihuany.

Powyższe dociekania mają oczywiście charakter czysto hipotetyczny. Pokazują możliwy scenariusz zdarzeń, według którego duża podaż i łatwa dostępność dopalaczy może przynieść w konsekwencji wyraźny i dość trwały wzrost rozpowszechnienia używania przez młodzież marihuany, a także wzrost (mniej trwały) w zakresie palenia tytoniu, picia alkoholu i upijania się.

W niniejszej pracy zaproponowano skorygowanie wskaźnika upijania się (binge drinking) przez dostosowanie go do płci, wieku i masy ciała respondentów. Potrzebna jest szersza dyskusja w gronie osób zajmujących się badaniami populacyjnymi młodzieży na temat standardów pomiaru upijania się. Można na przykład precyzyjniej szacować poziom intoksykacji, uwzględniając indywidualne dane na temat wieku, masy ciała i wzrostu [30], zamiast szacować parametry dla całych podgrup respondentów. Pomimo wielu niedoskonałości sko- 
dicator turned out to be structurally valid (in terms of suitability for respondents age and gender) and in line with the binge-drinking indicator based on one's own subjective assessment. This is a very interesting result also indicating the validity of the subjective indicator of binge drinking. Perhaps we ought to approach the own respondents' assessments with greater trust and accept that their answers to the simple question 'How many times (if at all) in the last 30 days, have you got drunk on alcoholic beverage?' give a sufficiently precise estimate of the prevalence of drunkenness episodes in the studied population.

Limitations. The use of differing survey questions severely hampered the comparison of results of various studies in the scope of the prevalence of psychoactive substance use. Especially doubts as regards the precision of comparisons concerned the survey questions on binge drinking.

In future studies and analysis it would be worth attempting to gain more precise BAC calculations taking advantage of individual, realistic data. Without this type of data (month of birth, body weight and height), this research has out of necessity conducted only a closer estimate of BAC for hypothetical, statistically average representatives of respondent subgroups for boys and girls of 15.5 years of age.

\section{- Conclusions}

The presented facts allow us to formulate a number of conclusions concerning the assessment of the prevalence of psychoactive substance use in Iława.

1. The results of the last edition of the Iława study from 2014 are favourable and show clear falls in recent years in the prevalence of drinking alcohol and binge drinking and the smoking of cigarettes in the population of 15-year-olds

2. In the same period, the consumption of designer drugs slightly increased from $2.4 \%$ to $5.2 \%$ while the drug use indicator remains at quite a high level of around $21 \%$ following the big rise in 2005-2012. These results suggest the need to undertake appropriate action by the police and other institutions in order to limit the illegal trade in drugs, especially the most popular rygowany wskaźnik binge drinking okazał się trafny strukturalnie (adekwatnie dopasowany do wieku i płci respondentów) oraz zbieżny ze wskaźnikiem upijania się bazującym na własnej subiektywnej ocenie. Jest to bardzo interesujący wynik, wskazujący także na trafność subiektywnego wskaźnika upijania się. Być może powinniśmy z większym zaufaniem odnosić się do własnych ocen respondentów i uznać, że ich odpowiedzi na proste pytanie: „Ile razy (jeśli w ogóle) w ciągu ostatnich 30 dni zdarzyło Ci się upić napojem alkoholowym?", dają dostatecznie precyzyjne oszacowanie rozpowszechnienia epizodów upijania się w badanych populacjach.

Ograniczenia. Stosowanie odmiennych pytań ankietowych bardzo utrudniało porównywanie wyników różnych badań w zakresie rozpowszechnienia używania substancji psychoaktywnych. Szczególne wątpliwości co do precyzji porównań wiążą się z pytaniami ankietowymi dotyczącymi upijania się (binge drinking).

W przyszłych badaniach i analizach warto podjąć próbę bardziej precyzyjnych wyliczeń BAC, wykorzystując indywidualne, rzeczywiste dane. Nie mając tego typu danych (miesiąc urodzenia, masa ciała, wzrost), w niniejszej pracy z konieczności dokonano jedynie przybliżonej estymacji BAC dla hipotetycznych, statystycznie przeciętnych przedstawicieli podgrup osób badanych, dziewcząt i chłopców w wieku 15,5 roku.

\section{- WNIOSKI}

Przedstawione wyniki badań pozwalają na sformułowanie kilku wniosków dotyczących oceny rozpowszechnienia używania substancji psychoaktywnych w Iławie.

1. Wyniki ostatniej edycji badań iławskich z 2014 r. są korzystne i pokazują wyraźne spadki w ostatnich latach rozpowszechnienia picia alkoholu i upijania się oraz palenia papierosów w populacji 15-letniej młodzieży.

2. W tym samym okresie wzrosła nieznacznie konsumpcja dopalaczy (z 2,4\% do 5,2\%), a wskaźnik używania narkotyków, po dużym wzroście w latach 2005-2012, nadal jest na dość wysokim poziomie, około $21 \%$.Wyniki te sugerują potrzebę podejmowania odpowiednich działań przez policję i inne instytucje w celu ograniczenia nielegalnego handlu narkotykami, w szczególności substancjami najbardziej 
substances like plant cannabinoids and their synthetics. It is also recommended to include young people in a universal prevention programme and prepare educators to undertake intervention.

3. The prevalence of drug use among young people in Iława is not especially large in the context of data from the country as a whole. In terms of the prevalence of drug use, but also cigarette smoking or also the prevalence of alcohol abstinence, the long-term trends in the Iława studies are a rather faithful reflection of the trends identified in national studies. The current levels of indicators value from the last Iława study editions and ESPAD are also very similar.

4. Frequent alcohol drinking (in the last 30 days) and binge-drinking in the population of 15 to 16 year-old Iława school students was clearly less prevalent than in the national population and the long-term trends are closer to that of the Warsaw youth subpopulation covered by the Mokotów studies.

5. The analysis of long-term trends conducted on the prevalence of psychoactive substance use proved the need for undertaking research editions more frequently than every four years, as well as the need for discussion and working out in the group of specialists of a standards of binge drinking measure in the study of young people of various ages. popularnymi - kannabinoidami roślinnymi i syntetycznymi. Wskazane jest także objęcie młodzieży programami profilaktyki uniwersalnej oraz przygotowanie wychowawców do podejmowania działań interwencyjnych.

3. Rozpowszechnienie używania narkotyków wśród iławskiej młodzieży nie jest wyjątkowo duże na tle danych $\mathrm{z}$ całego kraju, a raczej przeciętne. W zakresie rozpowszechnienia używania narkotyków, ale też palenia papierosów czy rozpowszechnienia zjawiska alkoholowej abstynencji, długoterminowe trendy $\mathrm{w}$ badaniach iławskich stanowią dość wierne odzwierciedlenie trendów identyfikowanych w badaniach ogólnopolskich. Aktualne poziomy wartości wskaźników $\mathrm{z}$ ostatnich edycji badań iławskich i ESPAD są również bardzo podobne.

4. Częste picie alkoholu (ostatnie $30 \mathrm{dni}$ ) i upijanie się w populacji 15-16-letniej młodzieży iławskiej było wyraźnie mniej rozpowszechnione niż w populacji ogólnopolskiej, a długoterminowe trendy bliższe są trendom $\mathrm{w}$ subpopulacji młodzieży warszawskiej, objętej badaniami mokotowskimi.

5. Przeprowadzone analizy długoterminowych trendów w rozpowszechnieniu używania substancji psychoaktywnych uwidoczniły potrzebę częstszego niż co cztery lata podejmowania kolejnych edycji badań populacyjnych oraz potrzebę dyskusji i wypracowania $\mathrm{w}$ gronie specjalistów standardów dla pomiaru upijania się w badaniach różnych wiekowo grup młodzieży.

\section{Conflict of interest/Konflikt interesów}

None declared./Nie występuje.

\section{Financial support/Finansowanie}

Each edition of the Iława studies were financed from Iława City Council budget funds dedicated to prevention and solution of alcohol problems./Kolejne edycje badań w Iławie sfinansowano ze środków budżetowych Urzędu Miasta Iławy, przeznaczonych na profilaktykę i rozwiązywanie problemów alkoholowych.

\section{Ethics/Etyka}

The work described in this article has been carried out in accordance with the Code of Ethics of the World Medical Association (Declaration of Helsinki) on medical research involving human subjects, EU Directive (210/63/EU) on protection of animals used for scientific purposes, Uniform Requirements for manuscripts submitted to biomedical journals and the ethical principles defined in the Farmington Consensus of 1997.

Treści przedstawione w pracy są zgodne z zasadami Deklaracji Helsińskiej odnoszącymi się do badań z udziałem ludzi, dyrektywami UE dotyczącymi ochrony zwierząt używanych 
do celów naukowych, ujednoliconymi wymaganiami dla czasopism biomedycznych oraz z zasadami etycznymi określonymi w Porozumieniu z Farmington w 1997 r.

\section{References/Piśmiennictwo}

1. Moskalewicz J, Kiejna A, Wojtyniak B (eds.). Kondycja psychiczna mieszkańców Polski. Raport z badań „Epidemiologia zaburzeń psychiatrycznych i dostęp do psychiatrycznej opieki zdrowotnej-EZOP Polska”. Warszawa: Instytut Psychiatrii i Neurologii; 2012.

2. Rada Miejska w Iławie. Miejski Program Profilaktyki i Rozwiazywania Problemów Alkoholowych oraz Przeciwdziałania Narkomanii na 2016 rok. Iława: Urząd Miasta Iławy - Ośrodek Psychoedukacji, Profilaktyki Uzależnień i Pomocy Rodzinie; 2015. http://bip.umilawa.pl/system/obj/8080_zal_AP_nr_XVIII_160_15_Zalacznik1.pdf [Accessed: 27.09.2017].

3. Policja warmińsko-mazurska. Itawa: debata spoleczna o zagrożeniach i profilaktyce zachowań ryzykownych. Iława 2015. http://www.warminsko-mazurska.policja.gov.pl/ol/ aktualnosci/10774,Ilawa-Debata-spoleczna-o-zagrozeniach-i-profilaktyce-zachowan-ryzykownych.html [Accessed: 27.09.2017].

4. Iławski dziennik internetowy Infoiława.pl. W Itawie trzeba ograniczyć podaż narkotyków. W'́ród gimnazjalistów bierze nawet co piąty. 4 czerwca 2015. http://www.infoilawa. $\mathrm{pl} /$ aktualnosci/item/2225-w-ilawie-trzeba-ograniczyc-podaz-narkotykow-wsrod-gimnazjalistow-bierze-nawet-co-piaty [Accessed: 27.09.2017].

5. Bobrowski K. Badania epidemiologiczne a kierunki rozwoju lokalnej strategii profilaktyki używania substancji psychoaktywnych. Badania iławskie. Alkohol Narkom 2003; 16(1-2): 39-56. http://ain.ipin.edu.pl/archiwum/2003/1-2/t16n2_3.pdf [Accessed: 27.09.2017].

6. Bobrowski K. Zmiany w rozpowszechnieniu używania substancji psychoaktywnych wśród gimnazjalistów w latach 2001-2005. Zagadkowe wyniki w Iławie. Alkohol Narkom 2007; 20(2): 133-50. http://ain.ipin.edu.pl/archiwum/1-2/t20n2_1.pdf [Accessed: 27.09.2017].

7. Bobrowski K. Rozpowszechnienie używania substancji psychoaktywnych wśród młodzieży gimnazjalnej w Iławie, 2001-2005-2010. Alkohol Narkom 2012; 25(1): 37-56. http://ain.ipin.edu.pl/archiwum/2012/1/t25n01_2.pdf [Accessed: 27.09.2017].

8. Bobrowski K. Raport z badań ankietowych rozpowszechnienia używania substancji psychoaktywnych oraz innych zachowań ryzykownych wśród uczniów iławskich gimnazjów 2014. Iława: Pełnomocnik Burmistrza Iławy ds. Rodziny, Profilaktyki i Rozwiązywania Problemów Uzależnień. http://www.osrodek.ilawa.pl/images/PDF/raport_zachowan_ryzykownych_2014.pdf [Accessed: 22.12.2017].

9. Sierosławski J. Używanie narkotyków przez młodzież szkolną. Wyniki ogólnopolskich badań ankietowych. Serwis Informacyjny Narkomania 1997; 1(6), 13-27.

10. Sierosławski J. Używanie alkoholu i narkotyków przez młodzież szkolnq. Raport $z$ ogólnopolskich badań ankietowych zrealizowanych w 2003 r. Europejski program badań ankietowych w szkołach ESPAD. Warszawa: Instytut Psychiatrii i Neurologii; 2003.

11. Sierosławski J. Używanie alkoholu i narkotyków przez młodzież szkolna. Raport z ogólnopolskich badań ankietowych zrealizowanych w 2015 r. Europejski program badań ankietowych w szkołach ESPAD. Warszawa: Instytut Psychiatrii i Neurologii; 2015. http:// www.cinn.gov.pl/portal?id=15\&res_id=1037524 [Accessed: 27.09.2017].

12. Wolniewicz-Grzelak B. Badania ankietowe nad spożywaniem alkoholu przez uczniów szkół ponadpodstawowych Mokotowa w 1984 roku i niektóre problemy metodologiczne. Biuletyn Instytutu Psychoneurologicznego 1985; 60(4): 65-85.

13. Wolniewicz-Grzelak B. Zmiany w spożywaniu przez młodzież napojów alkoholowych. Badania mokotowskie z 1984 i 1988 roku. Alkohol Narkom 1990; 3(2): 113-32. http:// ain.ipin.edu.pl/archiwum/1990/2/AiN_4-1990-09.pdf [Accessed: 27.09.2017].

14. Okulicz-Kozaryn K, Borucka A. Picie alkoholu przez młodzież z mokotowskich szkół średnich w latach 1984-2000. Alkohol Narkom 2001; 14(2): 245-59. http://old.ipin.edu. pl/ain/archiwum/2001/2/AiN_2-2001-08.pdf [Accessed: 27.09.2017]. 
15. Ostaszewski K. Trendy w używaniu przez młodzież substancji psychoaktywnych. Badania mokotowskie - kontynuacja. Alkohol Narkom 2001; 14(3): 387-406. http://old.ipin. edu.pl/ain/archiwum/2001/3/AiN_3-2001-08.pdf [Accessed: 27.09.2017].

16. Ostaszewski K (ed.), Bobrowski K, Borucka A, Okulicz-Kozaryn K, Pisarska A, Biechowska D, Shchudlo S, Klymanska L, Herasym H, Herus O, Savka V, Mirchuk I. Monitorowanie zachowań ryzykownych, zachowań nałogowych i problemów zdrowia psychicznego 15-letniej młodzieży. Badania mokotowskie 2004-2016. Badania ukraińskie, obwód lwowski 2016. Warszawa: Instytut Psychiatrii i Neurologii; 2017.

17. Pisarska A, Ostaszewski K. Pomiar rozpowszechnienia używania substancji psychoaktywnych przez młodzież. Przeglad Pedagogiczny 2015; 1: 137-51. http://repozytorium. ukw.edu.pl/bitstream/handle/item/3064/Agnieszka\%20Pisarska\%20Krzysztof\%20Ostaszewski\%20Pomiar\%20rozpowszechnienia\%20uzywania\%20substancji\%20psychoaktywnych\%20przez\%20mlodziez.pdf?sequence=1 [Accessed: 27.09.2017].

18. Jabłoński P, Malczewski A. „Dopalacze” - skala zjawiska i przeciwdziałanie. Warszawa: Krajowe Biuro ds. Przeciwdziałania Narkomanii; 2014. http://www.cinn.gov.pl/portal?id=15\&res_id=841820 [Accessed: 27.09.2017].

19. Najwyższa Izba Kontroli. Przeciwdziałanie sprzedaży dopalaczy. Informacja o wynikach kontroli. Wrocław: Delegatura NIK; 2017. https://www.nik.gov.pl/plik/id,13837, vp, 16274.pdf [Accessed: 27.09.2017].

20. Główny Inspektor Sanitarny. Dane z działalności Państwowej Inspekcji Sanitarnej w sprawie dopalaczy w latach 2011-2016. https:/gis.gov.pl/zdrowie/dopalacze/dane-statystyczne [Accessed: 27.09.2017].

21. Bobrowski K, Ostaszewski K, Pisarska A. Rekomendacje narzędzi do oceny zagrożeń zdrowia psychicznego młodzieży do dalszego stosowania w badaniach mokotowskich oraz w innych badaniach ankietowych mlodzieży szkolnej. Warszawa: Instytut Psychiatrii i Neurologii; 2007. http://old.ipin.edu.pl/wordpress/wp-content/uploads/2015/02/rekomendacje\%20narzedzi.pdf [Accessed: 27.09.2017].

22. Miech RA, Johnston LD, O'Malley PM, Bachman JG, Schulenberg JE \& Patrick ME. Monitoring the Future national survey results on drug use, 1975-2016: Volume I, Secondary school students. Ann Arbor: Institute for Social Research, The University of Michigan; 2017. http://monitoringthefuture.org/pubs.html\#monographs [Accessed: 27.09.2017].

23. Kolbowska A. Konsumpcja substancji psychoaktywnych przez młodzież szkolną. Serwis Informacyjny Narkomania 2009; 1(45), 33-41. http://www.narkomania.org.pl/ czytelnia/konsumpcja-substancji-psychoaktywnych-przez-mlodziez-szkolna/ [Accessed: 27.09.2017].

24. Malczewski A. Młodzież a substancje psychoaktywne. In: Młodzież 2016 raport z badania sfinansowanego przez Krajowe Biuro ds. Przeciwdziałania Narkomanii. Warszawa: CBOS; 2016, 200-25. http://www.cinn.gov.pl/portal?id=15\&res_id=1150305 [Accessed: 27.09.2017].

25. Sierosławski J, Bukowska B. Substancje psychoaktywne. Postawy i zachowania. Raport $z$ badań ankietowych zrealizowanych $w$ Łodzi w $2004 r$. Warszawa: Instytut Psychiatrii i Neurologii; 2004. http://bip.uml.lodz.pl/_plik.php?id=1653 [Accessed: 27.09.2017].

26. National Institute on Alcohol Abuse and Alcoholism (NIAAA). Drinking Levels Defined. https://www.niaaa.nih.gov/alcohol-health/overview-alcohol-consumption [Accessed: 27.09.2017].

27. White AM, Kraus CL, McCracken LA, Swartzwelder HS. Do college students drink more than they think? Use of a free-pour paradigm to determine how college students define standard drinks. Alcohol Clin Exp Res 2003; 27: 1750-6. http://dx.doi.org/10.1097/01. ALC.0000095866.17973.AF [Accessed: 27.09.2017].

28. Donovan JE. Estimated blood alcohol concentrations for child and adolescent drinking and their implications for screening instruments. Pediatrics 2009; 123(6): e975-81. http://dx.doi.org/10.1542/peds.2008-0027 [Accessed: 27.09.2017].

29. Hustad JTP \& Carey KB. Using calculations to estimate blood alcohol concentrations for naturally occurring drinking episodes: a validity study. J Stud Alcohol Drugs January 2005; 130-8. DOI: 10.15288/jsa.2005.66.130. 
30. Posey D, Mozayani A. The estimation of blood alcohol concentration: Widmark revisited. Forensic Sci Med Pathol 2007; 3(1): 33-9. https://link.springer.com/content/ pdf/10.1385\%2FFSMP\%3A3\%3A1\%3A33.pdf [Accessed: 27.09.2017].

31. Kulikowski P, Kostowski W. Alkohol etylowy i inne alkohole. In: Kulikowski P, Kostowski W (eds.). Farmakologia. Podstawy farmakoterapii. Podręcznik dla studentów medycyny. Warszawa: Państwowy Zakład Wydawnictw Lekarskich; 1985, 319-34.

32. Kułaga Z, Różdżyńska-Świątkowska A, Grajda A, Gorzkowska B, Wojtyło M, Góźdź M, et al. Siatki centylowe dla oceny wzrastania i stanu odżywienia polskich dzieci i młodzieży od urodzenia do 18 roku życia. Standardy Medyczne/Pediatria 2015; 12: 119-35.

33. Center for Behavioral Health Statistics and Quality. 2015 National Survey on Drug Use and Health: Detailed Tables. Rockville, MD: Substance Abuse and Mental Health Services Administration; 2016. https://www.samhsa.gov/data/sites/default/files/NSDUH-DetTabs-2015/NSDUH-DetTabs-2015/NSDUH-DetTabs-2015.pdf [Accessed: 27.09.2017].

34. SAMHSA's Center for the Application of Prevention Technologies. Sources of Consumption Data on Underage Drinking. https://www.samhsa.gov/capt/sites/default/files/ resources/consumption-data-underage-drinking.pdf [Accessed: 27.09.2017].

35. Boak A, Hamilton HA, AdlafEM, Mann RE. Drug use among Ontario students, 1977-2015: Detailed OSDUHS findings (CAMH Research Document Series No. 41). Toronto, ON: Centre for Addiction and Mental Health; 2015.

36. Kandel DB (ed.). Stages and Pathways of Drug Involvement. Examining the Gateway Hypothesis. New York: Cambridge University Press; 2002. 